\title{
The ABC Concept-Value Added to the Earth Heritage Interpretation?
}

\author{
M. Pásková ${ }^{1}$ (I) J. Zelenka ${ }^{1}$ (D) T. Ogasawara ${ }^{2} \cdot$ B. Zavala $^{3} \cdot$ I. $^{\text {Astete }}{ }^{3}$ \\ Received: 22 September 2020 / Accepted: 24 March 2021 / Published online: 17 April 2021 \\ (C) The Author(s) 2021, corrected publication 2021
}

\begin{abstract}
Holistic interpretation of Earth heritage is one of the most important tasks of UNESCO Global geoparks. The ABC (abiotic, biotic, and cultural interconnections) concept is a potential interpretive approach used in Earth heritage popularization through geotourism. Apart of the deeper understanding of this concept, this study explores the application of this concept in selected geoparks. The Colca and Volcanoes Andagua UNESCO Global Geopark (Peru) and Muroto UNESCO Global Geopark (Japan) served as a case study in the frame of this qualitative research conducted during the summer 2019. Results show that the ABC approach is nearly perfectly understood by both geoparks, however there are both internal and external factors which influence the extent and form of how this concept is applied in practice. Except for specific geographical settings, different stages of geopark product development, and different managerial approaches, they mainly include the level of scientific knowledge and general education in the given geopark, as well as level of knowledge management and networking with another UNESCO global geoparks. The more experienced Muroto Geopark interpretation exhibits a comparatively higher level of visible ABC application, while the Colca and Volcanoes Andagua Geopark can benefit in the future from the natural inclination and ability of the local people to integrate the cultural aspects into their Earth heritage interpretation.
\end{abstract}

Keywords ABC concept · Geopark · Earth heritage $\cdot$ Geotourism product · Interpretation

\section{Introduction}

When looking for the roots of major environmental problems, the disconnection of human from nature can be seen as common denominator, as a tax paid by humankind for its progress.

M. Pásková

martina.paskova@uhk.cz

J. Zelenka

josef.zelenka@uhk.cz

T. Ogasawara

tsubasa@muroto-geo.jp

B. Zavala

bzavala@ingemmet.gob.pe

I. Astete

iastete@ ingemmet.gob.pe

University of Hradec Králové, Hradec Králové, Czech Republic

Muroto Geopark Promotion Committee, Muroto, Japan

3 Instituto Geológico Minero y Metalúrgico, Lima, Perú
Geoparks are territories with an ambition to face these challenges together! They strive, in mutual synergy, to enhance human progress and to prevent the aforementioned gradual disconnection. One of their essential tools for revival or strengthening of human connection to Earth is the efficient interpretation of its geoheritage and its dissemination through enjoyable experience of the geotourism products. And one of the best opportunities to communicate the complex humanEarth interrelation is through "geostory" (Yuhora et al. 2014) reflected in development of interpretive materials, an activity typical for modern scientific diffusion. In this way geoparks can achieve their objective of making geoscience accessible and understandable to society, educating and informing nonexperts (Hilario 2018).

The ABC (abiotic, biotic, and cultural interconnections) concept represents an optimal way to elucidate the mutual links between abiotic, biotic, and cultural components of the geopark heritage, enabling a holistic understanding of its area. Geosites represent frequently specific habitats of various organisms, as well as sanctuaries or shrines for local and indigenous people (e.g., Pásková 2018). They can serve as a source of energy, an essential component of the fertile soil, both 
decorative and constructive material, and material for medicine, as well as an artistic inspiration, tourism attraction, or therapeutic space.

The enrichment of the geoparks concept by the $\mathrm{ABC}$ interpretive concept was an important milestone. The $\mathrm{ABC}$ interpretive concept was coined, comprehensively described by, and summarized by Dowling (2013). This approach represents a significant basis for the Earth heritage interpretation and is related not only to geotourism development, but also to the development of ecotourism in geoparks (Jaafar et al. 2014, 2015). The method of interpretation (Necheș 2016), as well as that of evaluation of the geoheritage (Fassoulas et al. 2012; Forte et al. 2012; Brilha 2016; Kubalíková 2013, 2017), including their classifications for the way they should be interpreted, have also been developed (Necheş 2016:80). Geodiversity (Gray 2008; Thomas 2016; Brilha et al. 2018 ) and related geosystem services (or abiotic ecosystem services-Gray et al. 2013:661-662) represent a fundamental basis for Earth heritage interpretation within the ABC concept (Fig. 1), as aptly formulated by Gray (2020:228). These mutual interrelationships are articulated in the description of the development of geodiversity and biodiversity in the history of the Earth (Gray 2008:289).

Another starting point for the interpretation within the $\mathrm{ABC}$ concept is the other two components of ecosystem services (Gray 2011) - biotic ecosystem services and cultural ecosystem services (Gordon 2018; Kubalíková 2020) which, according to Gordon (2018), arise as a result of human interaction, their values, and the environment. Modrej, Fajmut Štrucl and Hartmann (2018:106-109) presented examples of the best practice in the interpretation of geosites, including the $\mathrm{ABC}$ approach. The same applies to the technology and stepby-step manuals used for the interpretation of biotic, abiotic, and cultural heritage (FACET 2018). The specific "ABC synthesis" is paleontological heritage presentation and interpretation (e.g., Bruno et al. 2014; Moroni et al. 2015).

Ren, Simonson, and Pan (2013:119) emphasize the involvement of all the senses in transmitting awareness and experience of the abiotic, biotic, and cultural components of the geopark heritage to the visitor. They also stress the systemic concept of interpretive communication with the geopark visitor (Ren et al. 2013: 120).

Increased attention is paid to the research on perception of geological and other natural and cultural heritage (e.g., the

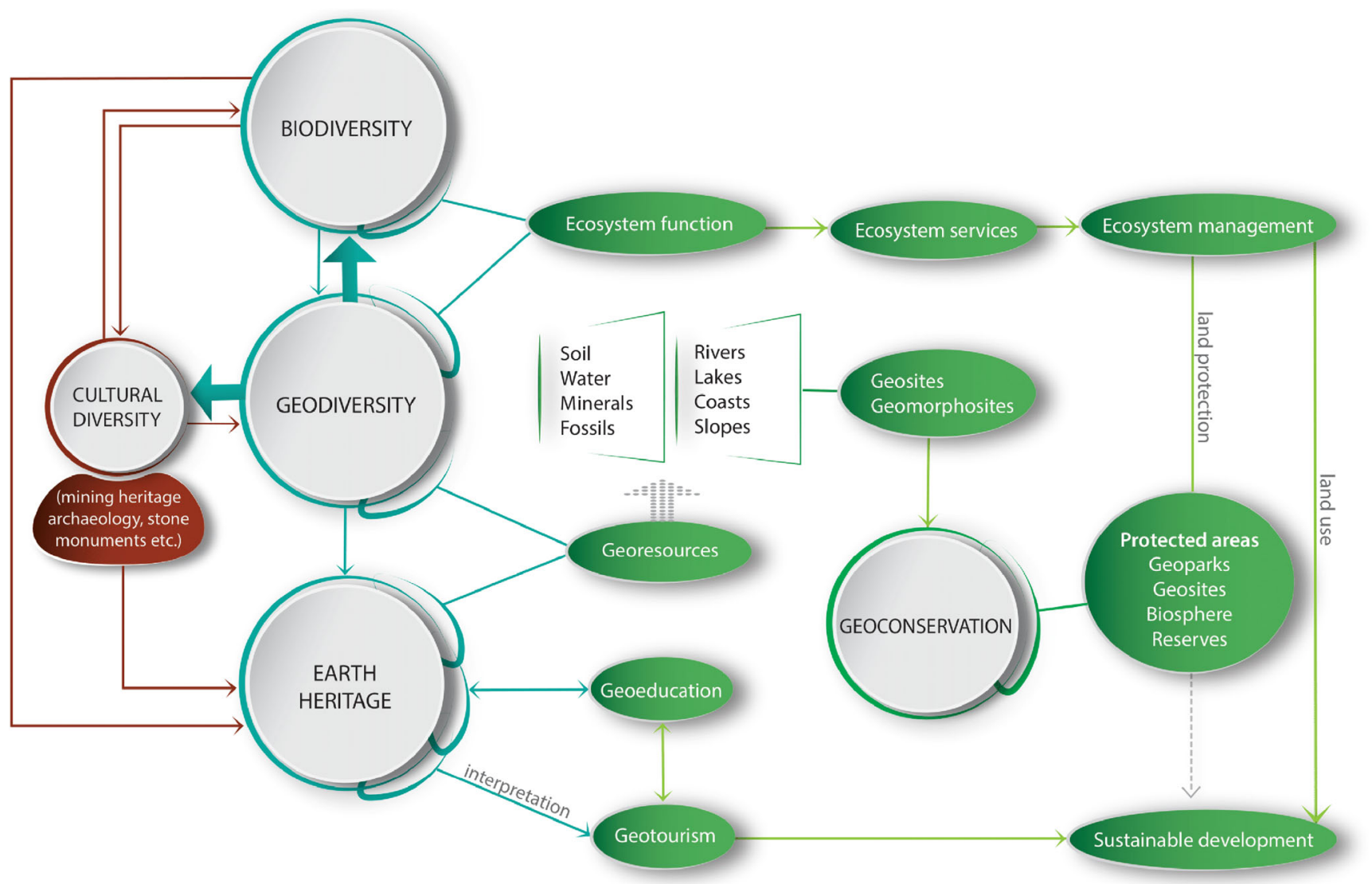

Fig. 1 Geodiversity and related geosystem services as a fundamental basis for Earth heritage interpretation within the ABC concept. Source: Based on Gray (2011:273), further developed 
visitor-employed photography method, Fung and Jim 2015) so that the way of presenting and interpreting this heritage can be optimized.

\section{Theoretical Background}

In recent years (Newsome et al. 2012; Du and Girault 2018), geotourism has become one of the major themes of sustainable tourism development (e.g., Farsani et al. 2009; Farsani et al. 2011; Farsani et al. 2013; Newsome and Dowling 2010; Pásková and Zelenka 2018a; Pásková and Zelenka 2018b). An important part of the development of geoparks is the protection of their geological heritage (de Carvalho 2014; Migoń and Pijet-Migoń 2016, 2017; Crofts 2019). There is an intense exchange of experiences in the geopark networks (at various geographical levels of this networking - national, continental, and global) and rich diversity of services for visitors are empirically described (e.g., Kajima et al. 2017; Tomić et al. 2015). However, a consistent approach to creating, promoting, segmenting, describing, and personalizing geopark products focused on the Earth heritage interpretation is still missing. According to Dowling (2013:65), geotourism product "embeds geoconservation, communicates and promotes geological heritage, and helps build sustainable communities through appropriate economic benefits." This definition is consistent with the essential concept of geoparks (e.g., Farsani et al. 2009; Farsani et al. 2011). The real challenge of this concept is how to achieve understanding of the mutual interconnections between geological, biological, and cultural heritage, and subsequently how to implement the abovementioned ABC concept (Dowling 2013) in the daily practice of Earth heritage interpretation.

The following scheme (Fig. 2) is inspired by the described role of geosites in the geoparks' offerings and by an analysis of the certification process of global geoparks (Pásková and Zelenka 2018a). It compares two different situations in the certified geoparks - the usual situation of a geopark product development (left side in Fig. 2) and the situation, when geopark management applies the $\mathrm{ABC}$ interpretive concept at the very beginning of its geotourism product development. Ideally, it should be applied in the first stage of the geosites' inventory and interpretation process (right side in Fig. 2). The usual situation (left side in Fig. 2) means that the geopark team gradually develops its products under specific external and internal conditions and certification rules, and gradually comes to understand the importance and benefits of the $\mathrm{ABC}$ concept. The right side in Fig. 2 demonstrates the situation in which the geopark team, after an initial geosites' interpretation development with emphasis on the abiotic component of the Earth heritage, moves quickly to developing geopark products within the $\mathrm{ABC}$ concept. Embracing this interpretive concept early results not only in faster deployment of more comprehensive geopark products but also in unlocking a much higher potential for better geopark product personalization, sustainability of development, improved destination management (e.g., Zelenka and Kacetl 2013), as well as to higher level of social capital and tourism sustainability. Such geoparks enjoy a competitive advantage compared to others and reduce their product development costs since no additional reinterpretation needs to be realized to enhance the geotourism product and to achieve the three-dimensional Earth heritage interpretation.

The scheme in Fig. 3 recalls conditions and contexts which should be considered and respected when developing a geopark product. When interpreting a geosite and creating a geopark product, it is appropriate to use different time scales (geological time, ecosystem time, psychological time) within the time context. In the spatial context, individual services for visitors and individual geopark products should be linked to the extensive thematic geopark product. In addition to the $\mathrm{ABC}$ interpretative concept, the application of the three-level product concept (total product; e.g., Horner and Swarbrooke 2016) is also recommended.

Another view of the holistically approached and interdisciplinary interpreted geopark product, seen in other contexts, reveals a mental map (Fig. 4), which was designed with the aim to reflect following questions:

- What can inspire and stimulate the geopark product in its different development stages and in its different domains, e.g., in its designing, realizing, or interpreting?

- Which concepts or approaches and what kind of cooperation enable the development and introduction of the geopark product?

- What represents the basis or essence of the geopark product, respectively, which conditions and criteria of its creation or development and its Earth heritage interpretation have to be fulfilled?

\section{Methodology}

The conceptual intention of the article was to provide a comprehensive set of appropriate approaches to the creation of geotourism products (specifically geopark products) focusing on application of the $\mathrm{ABC}$ interpretative concept. The qualitative strategy was adopted to frame this quest. Firstly, an extensive search of professional databases (especially ScienceDirect database) was carried out, complemented by the search of metainformation for professional articles using Google and Google Scholar. In this search, the focus was placed on geotourism, geotourism products (geoproducts) and geopark products, services offered to geoparks visitors, 
Fig. 2 Geopark product development scheme showing the process of a gradual understanding of the importance of respecting the $\mathrm{ABC}$ concept (left side), as well as the consistent use of the $\mathrm{ABC}$ concept from the early stages of geopark development (right side). Source: Based on Rodrigues and Carvalho (2009), Dowling (2013), Kubalíková (2013), and Gentilini (2016)

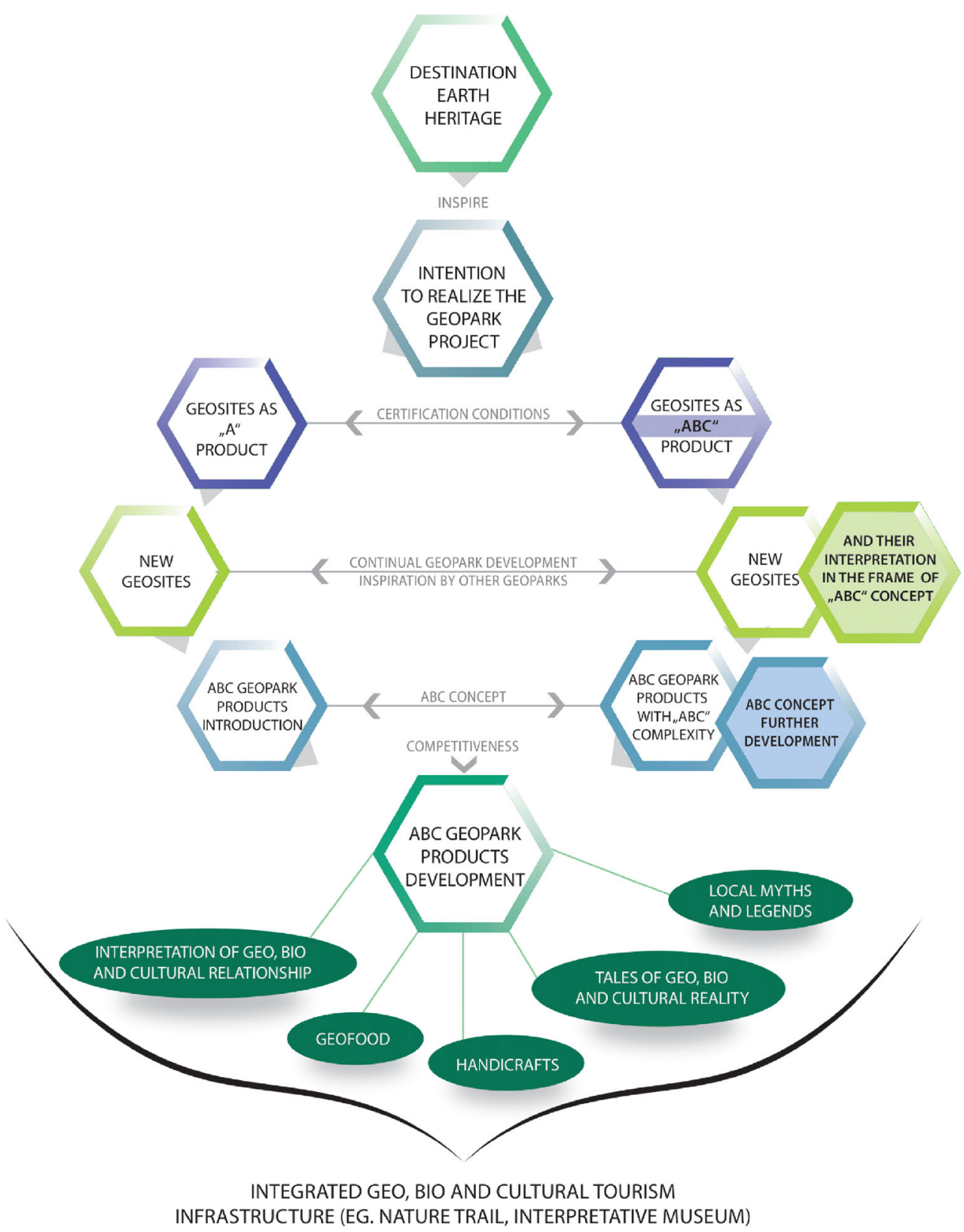

the geopark management process, the ABC interpretative concept, and the concept of three product levels (total product). The findings were expressed graphically in diagrams showing the comparison of geoproduct development with respect to the ABC interpretive concept at different stages of geopark product development, and in a schematic and mental map defining different contexts and different conditions of creation and development of geopark products.

This theoretical background was then applied to two case studies carried out in the Colca and Volcanoes Andagua UNESCO and the Global Geopark and Muroto UNESCO Global Geopark. The selection of these two research areas was driven by the intention to analyze application of the ABC concept in different geographical settings, as well in different developmental stages of geopark products, Earth heritage interpretation, and management approach. The aim of these case studies was to find out how the ABC concept is applied in the interpretation of both geoparks, in the context of global trends, theoretical background of geoproduct development and current knowledge of Earth heritage interpretation.

The interpretation of the selected geosites was analyzed through evaluation of the interpretive panels with the aim of detecting how the interrelationships between its abiotic, biotic, and cultural dimensions (ABC components) are clarified. For each analyzed geosite, the $\mathrm{ABC}$ components 
Fig. 3 Geopark product context. Source: Based on Dowling (2013), Zelenka et al. (2013), Horner and Swarbrooke (2016), and Pásková and Zelenka (2018a)

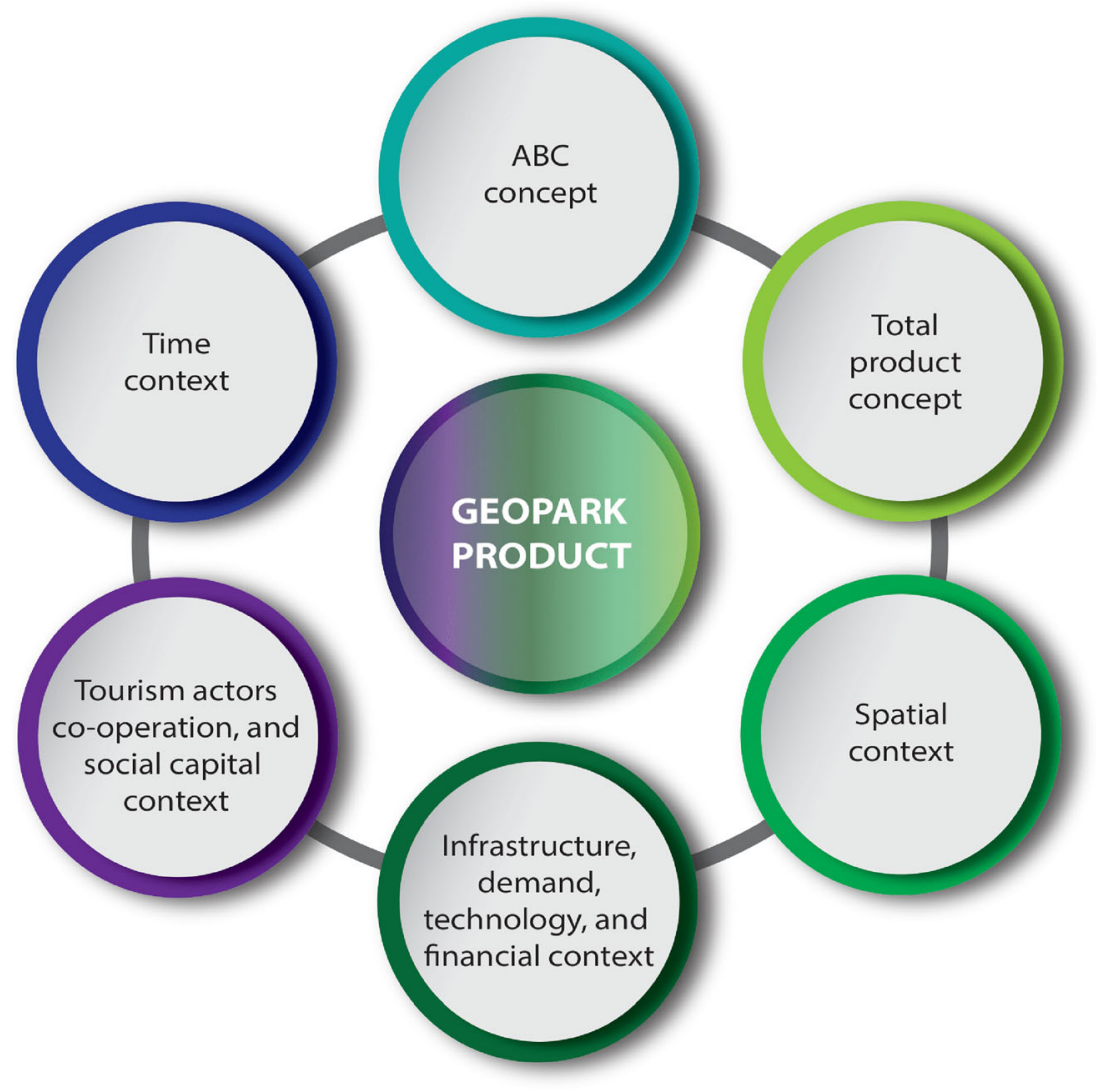

were identified, and then the evaluation of $\mathrm{ABC}$ concept applied in the interpretation of its Earth heritage followed. This assessment focused not only on the description of the ABC components of the Earth heritage of the given geosite but also on identification and explanation of their mutual interconnections. Additionally, in the case of absence of the interpretive panels, other types of accessible interpretative materials were assessed. The key methods thus consisted in the field research focused on the documentation of the interpretative panels at the selected geosites and semistructured interviews with key geoparks' informants (one for each geopark) focused on the interpretation system and development in the given geopark. Then, the qualitative analysis of collected data followed, supported by their comparison with the outcomes of the synthetic compilation of current theoretical knowledge.

As a frame for this research, the following mutually interrelated questions were formulated: In which way and intensity is the ABC concept applied in the geoparks' interpretative products? Which factors have influenced the development of the $\mathrm{ABC}$ concept application in the Colca and Volcanoes Andagua UNESCO Global Geopark and which ones in the Muroto UNESCO Global Geopark? Is the ABC concept application rather idiographic or rather nomothetic? To which extent is the application of this interpretive concept realized in one geopark replicable in another one?

\section{Case Studies}

\section{The Case of Colca and Volcanoes Andagua Geopark}

The Colca and Volcanoes of Andagua UNESCO Global Geopark (CVAUGG) was designated recently, in 2019. It covers a relatively large area of $6582.43 \mathrm{~km}^{2}$ situated in southern Peru (Fig. 5) which incorporates 19 districts of the Castilla and Caylloma provinces (Zavala et al. 2019). The highly complex geological history of this area is reflected in its exceptional geoheritage, recognized by Peruvian geologists and foreign researchers who made it known to the world. Among the most outstanding features belong more than twenty-five volcanic cones, as well as $100 \mathrm{~km}$ long and $3 \mathrm{~km}$ deep Colca Canyon, one of deepest in the world (Zavala et al. 2019).

There are the oldest rocks of the geopark in the Colca Canyon sector. They correspond to gneiss, amphibolites, and Precambrian granulites (Basal de la Costa Complex; $540 \mathrm{Ma}$; Caldas 1993). In discordance, and with Paleozoic absence, it exhibits a small sector with volcanic and marine calcareous 


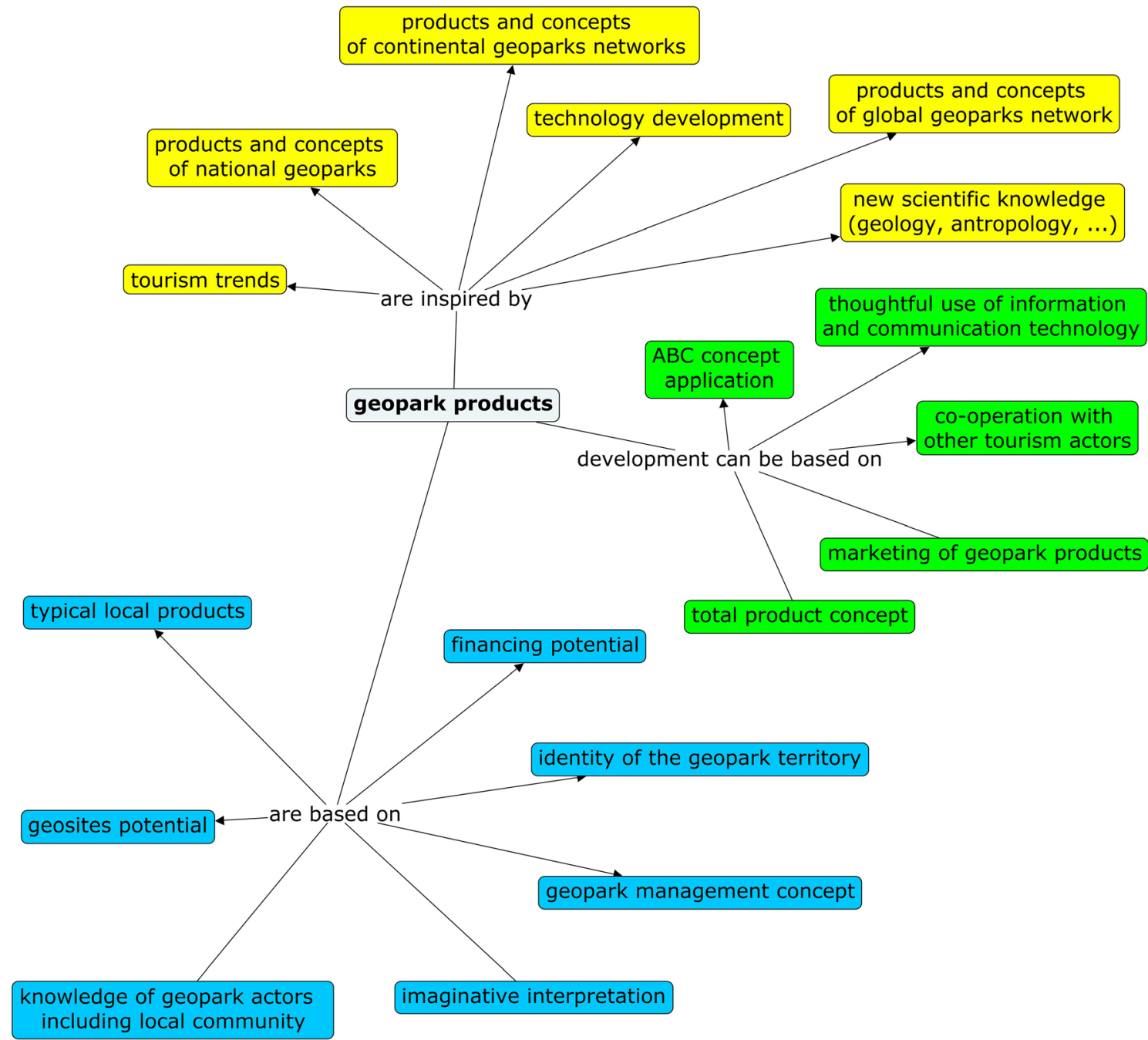

Fig. 4 Mental map of development of the interpretive geoproducts. Source: Based on Azman et al. (2010), Dowling (2013), Rutherford et al. (2015), Martínez-Graña et al. (2017), Farsani et al. (2017), Kajima et al. (2017), and Pásková and Zelenka (2018a)

Jurassic rocks (174-163 Ma). A marine transgression occurs in the late Jurassic and throughout the Cretaceous. Sandstones, shales, and limestone strata with marine fossils, evaporite levels, and continental red capes indicate a gradual withdrawal from the Cretaceous seas (177-66 Ma), occupying the west geopark sector (Romero and Ticona 2003). Intrusive bodies of the Andean Batholith, folding in the Mesozoic strata are associated with a regional uprising and the first Andean tectonic phase (66-28 Ma), generating thick sequences of conglomerates, sandstones, and volcanic breccia. Between 23 and 13 $\mathrm{Ma}$, intense volcanic activity was generated, related to a second Andean tectonic phase. Thick sequences of lava, ignimbrites and volcanoclastic material occur at this time. The oldest stratovolcanoes originate between 6 and $4 \mathrm{Ma}$. They occupy the upper slopes of the Colca Valley; one of them the Mismi volcano, a snowy geosite which gives rise to the Amazon River. Wide volcanic plains and ignimbrites plateaus and lava flows are associated with this volcanism. It is followed by volcanoes of the second generation (4 and 2 Ma), highlighting lava flows from the Hualca Hualca volcano occupying the most pronounced Colca Canyon section (Zavala et al. 2019). The youngest volcanoes are Ampato and Sabancaya with eruptive historical activity.

The Plio-quaternary geodynamic and neotectonic activity shapes the current geopark landscape. The volcanic avalanche of Hualca Hualca and the deposits of the Colca paleolake that occupy the valley are relevant; seismite structures in the deposits show a high seismicity of active faults that predominate to date (Benavente et al. 2017). One of the stages geologically known as Andagua Volcanism occurred during the Pleistocene-Holocene $(0.53$ and $0.2 \mathrm{Ma})$. It covers and fills large areas in the Colca region, creating an impressive landscape, unique in the country, which shows the Andagua Volcanoes Valley (Zavala et al. 2016). From dates of eroded hanging lavas in the Colca Valley, two incision stages of the Colca Canyon 


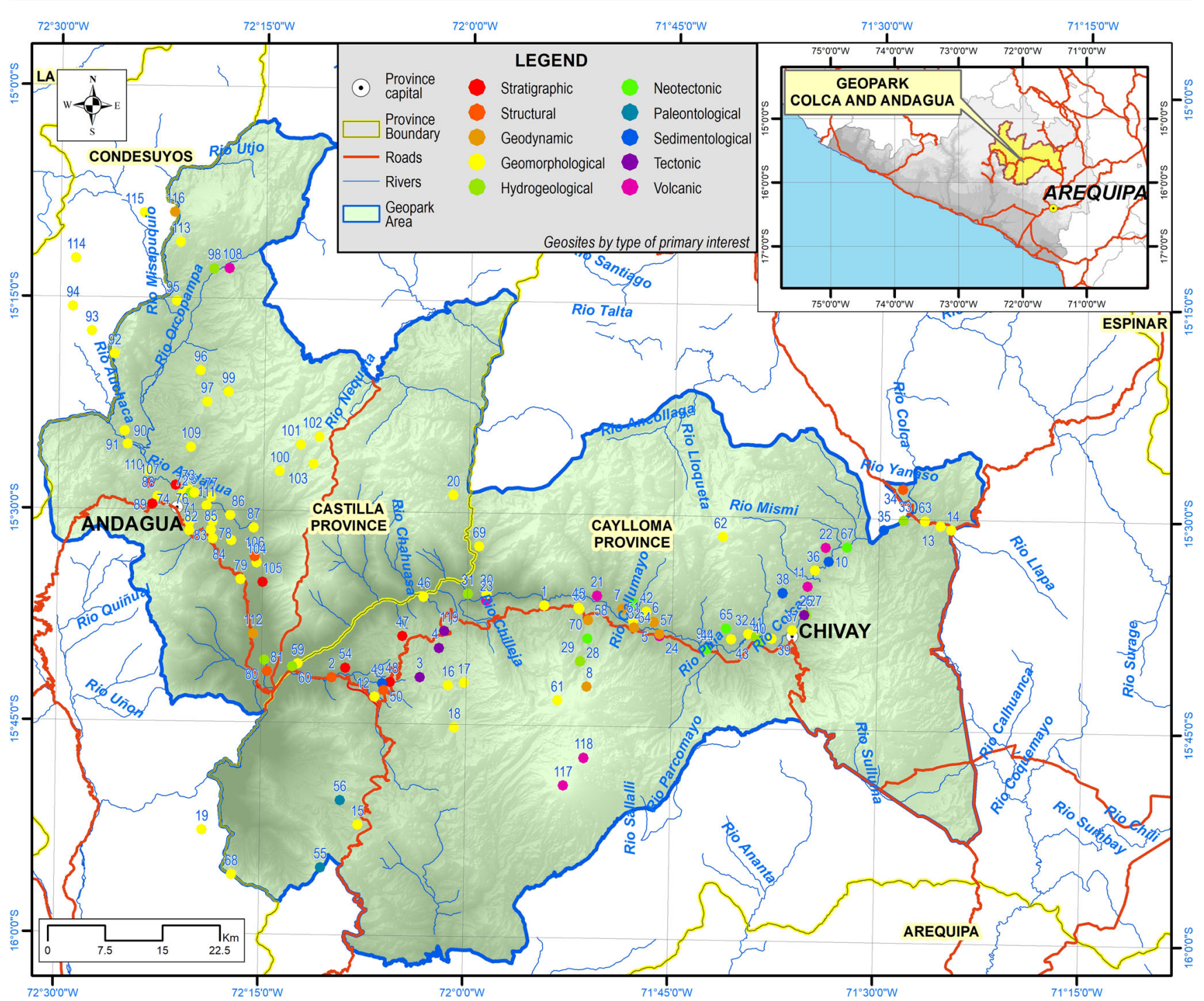

Fig. 5 Map of the Colca and Volcanoes Andagua UNESCO Global Geopark. Source: UNESCO (2015)

have been differentiated: one 1.6 Ma ago and the other between 0.65 and $0.61 \mathrm{Ma}$ ago (Thouret et al. 2007).

The soil in the Colca Valley, which is predominantly of alluvial and lacustrine character with fragments of volcanic material, is noted for its natural fertility. This property encouraged the ancient Peruvians (including Incas) in the construction of andenerias (system of agricultural terraces) enabling the control of soil erosion and landslides, water regime and proper management of crops (Málaga 1986). On the other hand, these platforms modified the soil and climate conditions, in the way appropriate for agriculture on steep slopes. There are many other phenomena related to the relationship between human activities and geological processes in the Colca Valley, documenting the human occupation of this geographical space like stone colcas, pre-Inca circular storage constructions made of the local volcanic and sedimentary rock or chullpas, funerary stone towers originally constructed for noble persons. Altogether, these features represent good examples of interrelated $\mathrm{ABC}$ components of the CVAUGG Earth heritage.

The geopark has 119 geosites, five of them have been assigned as sites of international value (Colca Canyon; El Mismi - Headwaters of the Amazon River; Andagua Volcanoes Valley; Mamacocha lagoon resurgent aquifer; Neotectonic trench El Trigal fault). The work of the Polish experts (Paulo and Gałaś 2008) contributed substantially to the geopark's Earth heritage description. It includes the geopark's landscape and the human modifications and adaptations for coexisting with the phenomena of this territory (glaciers, volcanoes, rivers, and mountains), so called cultural landscape, which interrelates human, nature, and its landscape, giving it a cultural identity.

\section{The Case of Muroto Geopark}

The Muroto UNESCO Global Geopark (MUGG) was designated as a UNESCO Global Geopark in 2011. It is located in 
Fig. 6 The location of the Muroto UNESCO Global Geopark. Source: UNESCO (2019)
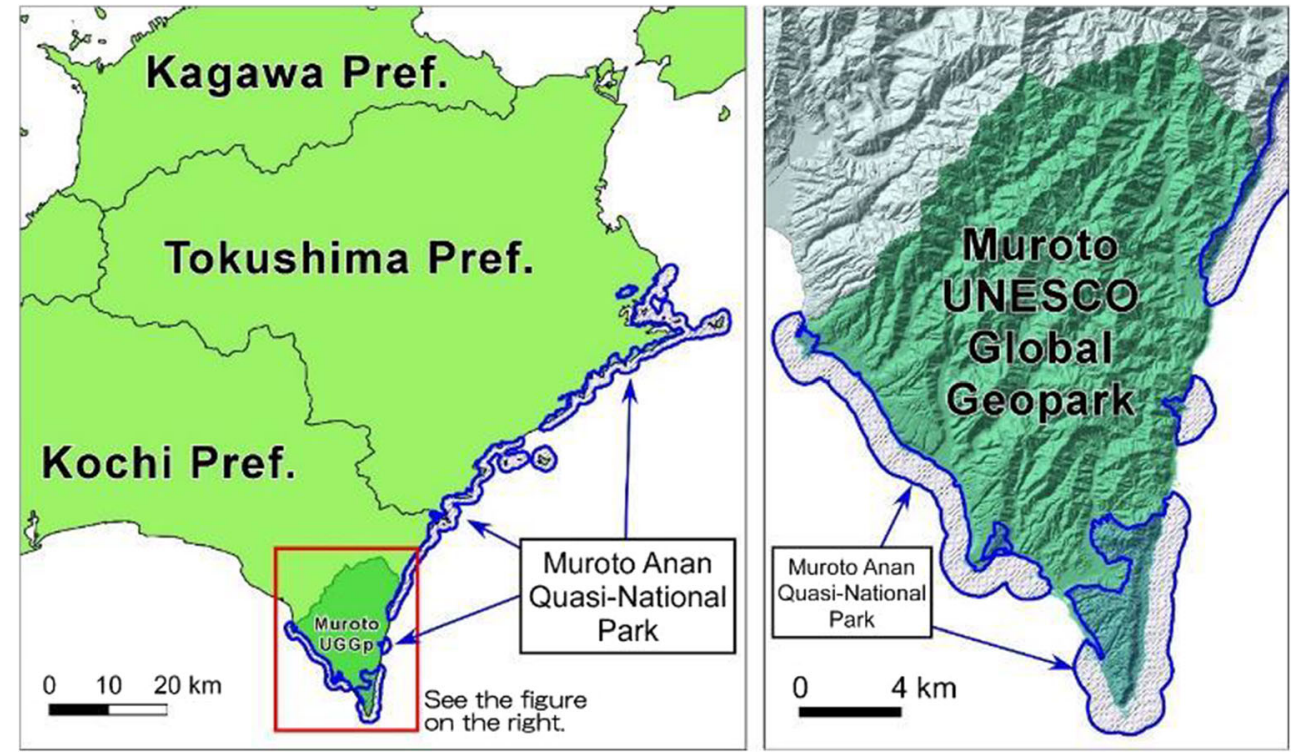

Kochi Prefecture on Shikoku Island, in the southwestern part of the Japanese archipelago (Fig. 6), and includes all the administrative territory of Muroto City (UNESCO 2019). Majority of its area has mountainous character, and the mountain range at its northern margin is approximately $1000 \mathrm{~m}$ high (UNESCO 2019). The MUGG is geologically characterized by accretionary complex formation and associated magmatic intrusion, sedimentation on top of the accretionary complex and uplift caused by earthquakes.

This territory shows one of the best-understood and youngest accretionary complexes in the world (Paleogene to Neogene). It contains many proofs of the typical sedimentation process that occurs at a subduction zone. Ridge subduction during the accretion process resulted in igneous activity leading to the formation of gabbroic rocks and volcanic rock, pillow lava, both of which were formed approximately 15 to $14 \mathrm{Ma}$. The alternating sandstone and mudstone layers which constitute the accretionary complex, adjacent to the igneous rock, were affected by contact metamorphism. The upheaval of Cape Muroto is best represented by the Quaternary marine terraces on the west coast of the cape. Several wave-cut platforms of varying heights formed in this region 160,000 years ago. Each of the platforms here was formed by the glacialinterglacial sea level changes and coseismic uplifts (Muroto Geopark Promotion Committee 2011).

Around the Nankai Trough, large subduction-zone earthquakes of magnitude eight have repeatedly occurred at an interval of 100 to 150 years, and caused massive tsunamis. The MUGG is the only UNESCO Global Geopark expecting a large-scale earthquake predicted in the near future, so they collaborate with scientific partners to establish a prediction model of such earthquakes by drilling in seismogenic faults, as well as state-of-the-art research using ocean bottom seismometers. This has been conducted as a national project at the
Nankai Trough. The Muroto Geopark has 78 geosites; 16 of them have been assigned by the Muroto Geopark as international value sites, e.g., the Cape Muroto area-Turbidites and Nishiyama Plateau-Marine Terraces. The Geopark works as a link between the local municipality and locals to promote collaborative conservation efforts. Local guides serve a vital role in site protection, as they patrol sites and give tours nearly every day (Muroto Geopark Promotion Committee 2019).

\section{Results}

\section{The Current Application of the ABC Concept in the CVAUGG}

In the Colca and Volcanoes of Andagua UNESCO Global Geopark, the analysis carried out to interpret the CVAUGG geosites had from the very beginning the philosophy of registering abiotic Earth heritage components and evaluating them for their scientific, tourist and educational value, but also highlighting associated aspects regarding biodiversity (living nature aspects) and the human presence (cultural aspects). The 119 geosites found in the geopark territory mainly present geological phenomena, and another 51 focuses on cultural characteristics. However, among these 170 sites, a large number comprise two or three of these $\mathrm{ABC}$ aspects.

The interpretation evolution of the geopark's Earth heritage through geosites, geotrails, geoguides, interpretive panels, brochures, books, magazines, videos, etc., enables researchers to approach it in a different way and improve the future CVAUGG implementation plans. The importance of local and indigenous knowledge for the interpretation of the CVAUGG Earth heritage has been recognized from the early 
stages of this process; however, it is still not used significantly in the interpretative panels at the touristic geosites.

Based on the local socio-cultural context, the CVAUGG team has naturally embraced the potential of the "geostory" (Yuhora et al. 2014) and "geomyths" (Vitaliano 2007; Kirchner and Kubalíková 2015) for interpreting its Earth heritage. The evaluation carried out to explain the processes of land formation and define its geological heritage was developed by the CVAUGG geologist. Geographical and cultural information is perceived by the CVAUGG team as an integral part of the interpretive message that has to be adjacent to each geosite interpretation in the future (Fig. 7).

Regarding the development of interpretive panels, a major challenge for the CVAUGG team is to "explain Earth Sciences for school-age children." For this purpose, local geoscientists work together with other personnel (journalists, cartoonists, historians, etc.) and also with local and indigenous people. The advantage of the locals is their ability to spread cultural and historical information of the Colca and Andagua Volcanoes region. The CVAUGG team communicates intensively with local municipalities to promote collaborative conservation efforts. Local geoguides are being trained to play a vital role in the Earth heritage presentation and conservation.

In the mission of carrying out geoeducational work and promoting Earth heritage through geotourism and revitalizing the CVAUGG economy, the first interpretive panels provide information on main geological processes and strategic geopark localities (10 panels). These panels try to elucidate the concept of the geopark, and the value of the local geoheritage in the most attractive sites, drawing attention of visitors to geological aspects that affect them (volcanoes, landslides, earthquakes, faults). In this sense, the intention is to "provoke," through interpretation, curiosity to learn more about the origin of a landscape, which has a great component in geology, despite the difficulties of understanding geological time or excessive physical magnitudes, which are often abstract. The biotic and culture aspects of the given geosite and their links to the geological and other abiotic phenomena are interpreted there just marginally or they are not interpreted at all.

The CVAUGG team strives to achieve the geopark's potential to reach sustainable development goals: (Aranibar and Ayerbe 2015) "To let local and indigenous people value what is known" (geoheritage); (Azman et al. 2010) to let them understand that there are spectacular sites waiting for explanation; (Benavente et al. 2017) to let them understand climate change and the origin of disasters; (Brilha 2016) to enhance sustainability of their use of natural resources; and (Brilha et al. 2018) to support with scientific knowledge their intuitive understanding that the geodiversity is the basis for biodiversity, traditions, history, customs, gastronomy, life style, and rural/urban development. Communicating these connections between geoheritage, the ecosystems, and the culture of the Earth to the local inhabitants and visitors, the panels cover different domains. For main geological aspects of the CVAUGG territory (for example, explaining particular rock aspects and their natural environment), this can be done with a small panel, linking the two, using simple words and pictures. Instead, to convey more complete information on each geosite, focusing on its "geostory," a large panel will be required. Its location should be attractive to the visitor or local inhabitant, showing a geographical history of that connection between nature and people's lives. This is planned to be undertaken in various geosites that are described below, which will allow the $\mathrm{ABC}$ concept to be further developed.

Geoparks are not static, and new interpretations may emerge reflecting their dynamics. Even the initial inventory

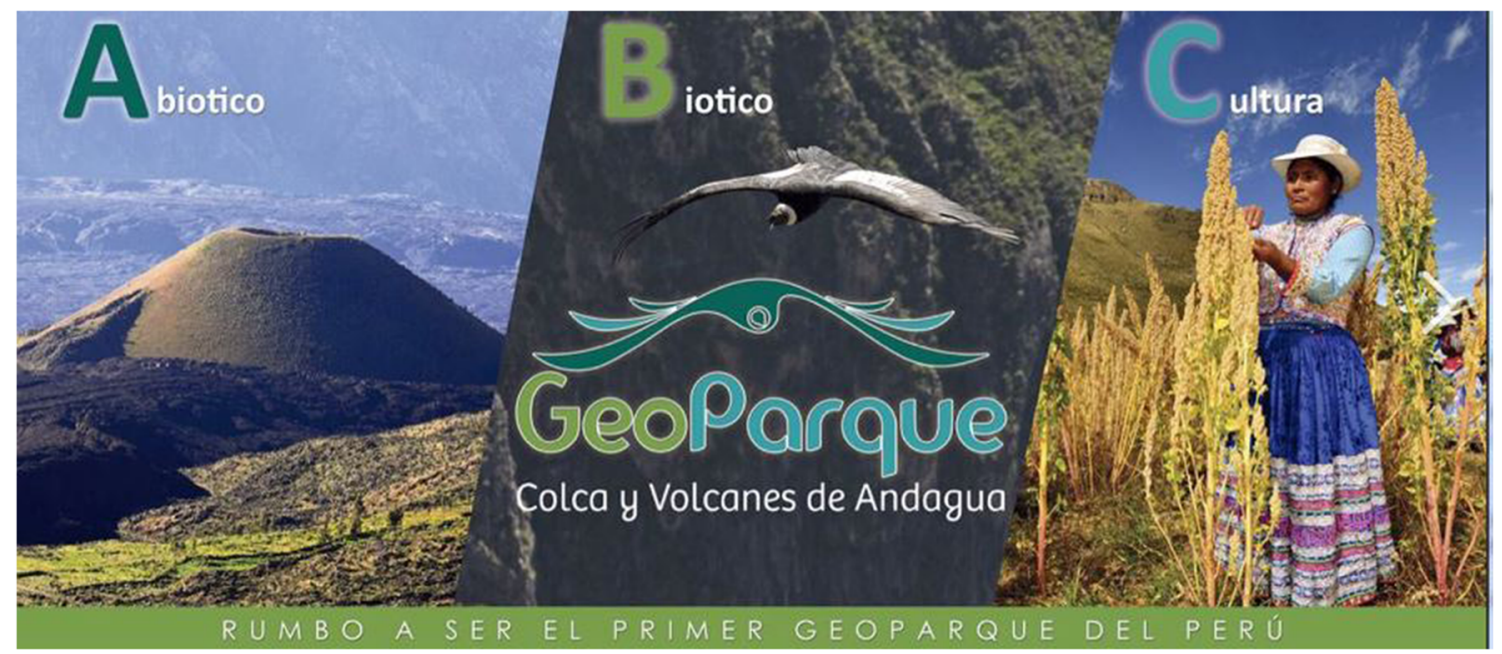

Fig. 7 The reflection of ABC concept in the interpretive approach of the Colca and Volcanoes Andagua UNESCO Global Geopark. Source: Colca and Volcanoes Andagua (2020) 
of geosites requires periodical update. As documented by Pásková (2018), participatory knowledge management, realized by involvement of people from the local and indigenous communities, allows that. This way of showing the connection between geology/geography, ecosystems, and culture more clearly made by the exchange of experiences in GEOLAC (Latin American and Caribbean Geoparks Network), or through the GGN (Global Geoparks Network), need to be considered. The local population then feel more committed and proud when some geosites located in their community are included (e.g., Pásková 2018). The CVAUGG team also promotes Earth heritage care and geoconservation. In the 170 geosites, the inventory matrix is divided into three categories: geological, combined, and historical-cultural.

The improvement and update of the geosite inventory allow the review of the initial design of the interpretive panels within the Geopark. Ten analyzed geosites, for which the new interpretive panels are prepared, contain the $\mathrm{ABC}$ information. An analytic description and sample of cultural and ecological information, in addition to the geological (abiotic) one, are described in Table 1 . Illustrative graphics on the origin of the landscape, photos, and didactic description show how the not only "pure" geology but also the cultural environment around the site, such as the development of festivities and traditional or local ancestral customs that make up the "Pachamama" philosophy, are interpreted.

Methods for interpreting the Earth heritage in the CVAUGG have changed over time. The strict application of geoscientific knowledge has not proved to be optimal. In this sense, the work with the association of local guides, tourism students in the Colca Canyon and in the Andagua Volcanoes Valley, as well as interaction with official tourist guides in Arequipa, has potential for developing the interpretation skills in geological, geographic, ecological, and cultural processes and their mutual relationships. The approach to development of the new geotrails in cooperation with the local students and guides is described in the CVAUGG Geotourism Development Plan.

As documented by Pásková (2018), the territorial knowledge of the geopark through interviews or conversations with indigenous people allows registering cultural and historical events that many do not know. According to her, transmission of this kind of knowledge is very important for the territorial identity of local population. One of the examples, described in Table 1, shows the elaboration of stories by local children, esteeming a Laguna Mamacocha geosite through the book "My grandfather told me." The local Elders are proud to pass that knowledge to younger generations. They generally do so through stories, myths, or legends about their natural environment or Earth heritage. They are important resources for the CVAUGG team to know how the Earth heritage in the region has been recognized and interpreted by its local people.

\section{The Current Application of the ABC Concept in the MUGG}

In the Muroto UNESCO Global Geopark, "geostorytelling" has come to be the basis for Earth heritage interpretation. First, "geostory" was developed by a geologist, and had thus a purely geological character explaining land formation processes. Then more complex, geographical information was added to the geostory to reach a more comprehensive interpretation of each of the geosites (Matsuki and Sasao 2015). Geostory is really a key word for the MUGG team to consider Earth heritage interpretation. A former MUGG geographer, major in anthropogeography, defined "geostory" in two categories: (Aranibar and Ayerbe 2015) geological story which explains mutual influence/relations of geological phenomenon, and (Azman et al. 2010) geographical story which explains relations between landscape and geology (nature) and people's lives including local ecosystems (Yuhora et al. 2014).

The biggest change since its designation as UNESCO Global Geopark is that the MUGG team worked to improve the inventory and assessment of geosites based on recommendations from a revalidation mission realized by UNESCO experts in 2015. There used to be 22 geosites covering wide areas and focusing on several different themes (Muroto Geopark Promotion Committee 2019). Those 22 geosites were separated into multiple sites with specific locations, with themes falling into three categories (geological, ecological, and cultural). In 2018, a new geosite inventory was developed with 51 geosites, 10 ecological sites, and 17 cultural sites. Each of the new sites focuses on a more definitive and specific theme. It allowed the MUGG to show connections between geology/geography, ecosystem, and culture more clearly, as described in Table 2. After this geosite-inventory improvement in 2018, the MUGG team started to revise all the interpretive panels within the geopark. Ten new interpretive panels were also introduced at this time.

Developing interpretive panels is perceived by the MUGG team as one of the best opportunities to conceptualize Earth heritage interpretation as a geostory. According to the MUGG team and as it is visible from the interpretive panels, the big theme of interpretation developing has been always "explaining Earth science for 12-year-old children." Therefore, the local Earth scientists work together with other staff or locals who are not specialists in geology and bring the cultural context of Muroto including its intangible heritage which is crucial for the geostory.

Regarding the MUGG interpretation system, a geopark has two types of interpretive planes: one has a small format (35 panels) which mainly tells visitors specific information about geological phenomenon; and one is a large format (33 panels) which tries to tell visitors about connections between Earth heritage, ecosystem, and culture. Those differently sized panels have different roles. Cape Muroto, as the area covering 
Table 1 Analysis of the ABC concept application in the interpretation of the Colca and Volcanes de Andagua UNESCO Global Geopark

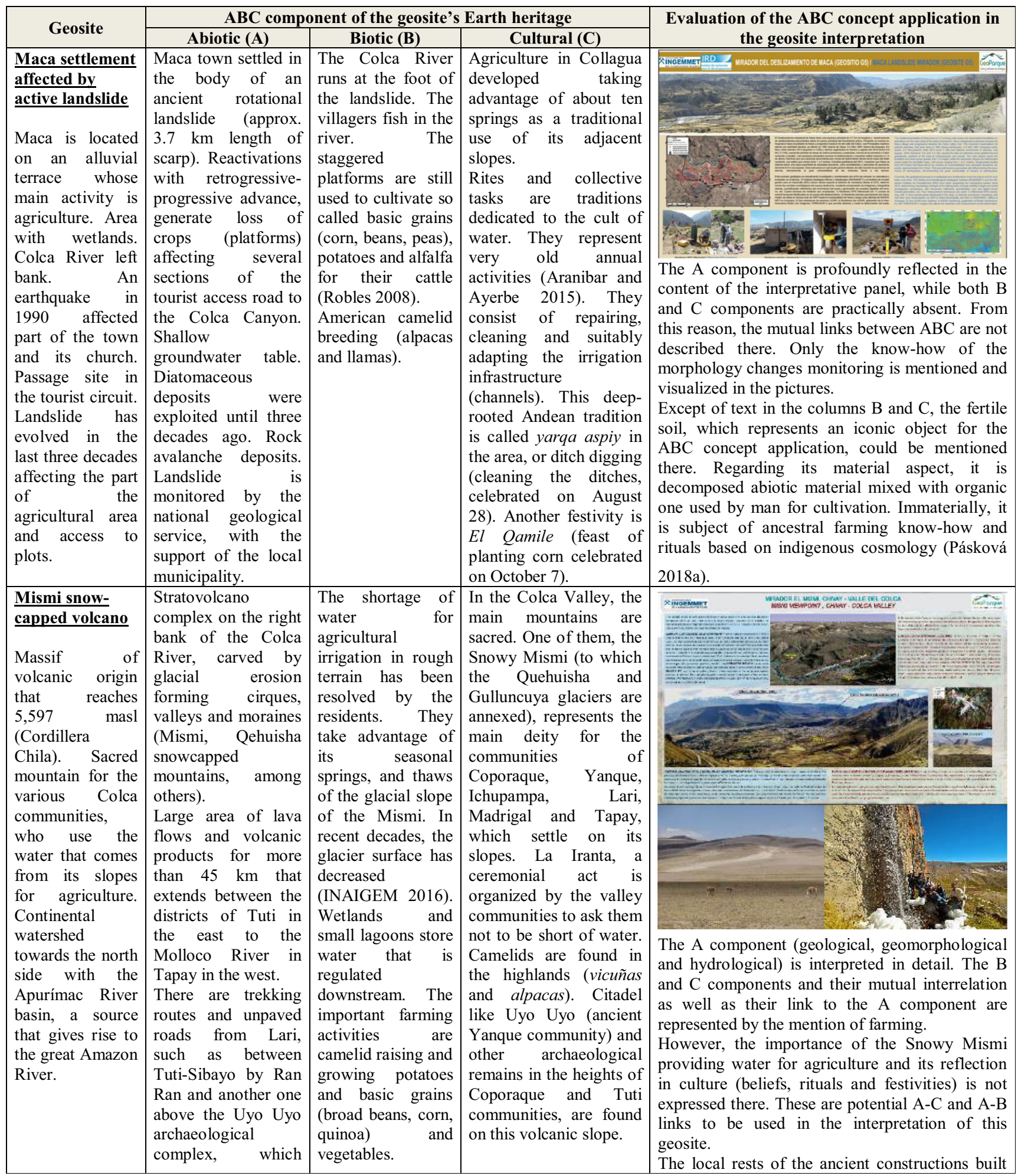




\begin{tabular}{|c|c|c|c|c|}
\hline & ascend to the Mismi. & & & $\begin{array}{l}\text { of the local volcanic material should be also } \\
\text { mentioned to enrich the A-C interpretation } \\
\text { aspects. }\end{array}$ \\
\hline $\begin{array}{l}\frac{\text { Mamacocha }}{\text { lagoon }} \\
\underline{\text { resurgent }} \\
\text { aquifer } \\
\text { An oasis, in a } \\
\text { depression } \\
\text { generated by } \\
\text { several lava } \\
\text { flows, whose } \\
\text { waters include } \\
\text { fish, the Pacific } \\
\text { otter, unique and } \\
\text { vulnerable fauna. } \\
\text { It represents a } \\
\text { tourist site and } \\
\text { icon of the Ayo } \\
\text { district, which } \\
\text { can be accessed } \\
\text { by a carriage } \\
\text { trail, or a walking } \\
\text { trail. On its right } \\
\text { bank, remains of } \\
\text { human } \\
\text { occupation of the } \\
\text { first settlers can } \\
\text { be observed. The } \\
\text { lagoon drains } \\
\text { into the Colca } \\
\text { River. }\end{array}$ & $\begin{array}{l}\text { Resurgent aquifer in } \\
\text { lavas of the Andagua } \\
\text { Group that gives rise } \\
\text { to the Mamacocha } \\
\text { lagoon, in the Ayo } \\
\text { district, valley of the } \\
\text { volcanoes. The } \\
\text { waters that are lost } \\
\text { or infiltrate the } \\
\text { Chachas lagoon, } \\
\text { below lava flows, } \\
\text { run as an } \\
\text { underground river } \\
\text { for } 17 \text { km and } \\
\text { resurface in } \\
\text { Mamacocha with a } \\
\text { flow of } 10.5 \mathrm{~m}^{3} / \mathrm{s}^{-1} \text {, } \\
\text { an exceptional } \\
\text { lagoon originated by } \\
\text { three lava flows. The } \\
\text { porous lavas behave } \\
\text { like an aquifer, while } \\
\text { the sedimentary units } \\
\text { found underneath, as } \\
\text { an impermeable } \\
\text { basement. }\end{array}$ & $\begin{array}{l}\text { According to } \\
\text { geopark informant, } \\
\text { the Andean otter } \\
\text { population would } \\
\text { be the only one } \\
\text { found between } \\
\text { northern Peru and } \\
\text { southern Chile, } \\
\text { perhaps related to } \\
\text { the Amazonian } \\
\text { otter. This } \\
\text { ecosystem registers } \\
\text { an important } \\
\text { grouping of bats, } \\
\text { with seven species, } \\
\text { that disperse cactus } \\
\text { seeds, and allow } \\
\text { thus regeneration } \\
\text { of vegetation; they } \\
\text { pollinate the } \\
\text { flowers of the } \\
\text { cacti, promoting } \\
\text { their reproduction; } \\
\text { they also } \\
\text { contribute to the } \\
\text { control of the } \\
\text { insect populations. }\end{array}$ & $\begin{array}{l}\text { The huallaque or } \\
\text { Andean otter" is thought } \\
\text { to be the true Mayopuma } \\
\text { venerated in Andean } \\
\text { cultures. There are also } \\
\text { preserved rock art } \\
\text { samples along a path } \\
\text { that goes down to the } \\
\text { lagoon (rock paintings } \\
\text { on the rocky walls). } \\
\text { They express the art of } \\
\text { the pre-Inca period, with } \\
\text { figures of llama herding } \\
\text { and people. } \\
\text { An example of imprint } \\
\text { of the Ayo's cultural } \\
\text { memory is the storybook } \\
\text { titled "My grandfather } \\
\text { told me: Ayo stories, } \\
\text { myths and legends." } \\
\text { There are } 29 \text { short } \\
\text { stories written by } \\
\text { children, with the } \\
\text { support of parents and } \\
\text { grandparents } \\
\text { highlighting the value of } \\
\text { Laguna Mamacocha. } \\
\text { This book will be re- } \\
\text { edited for further } \\
\text { dissemination. }\end{array}$ & 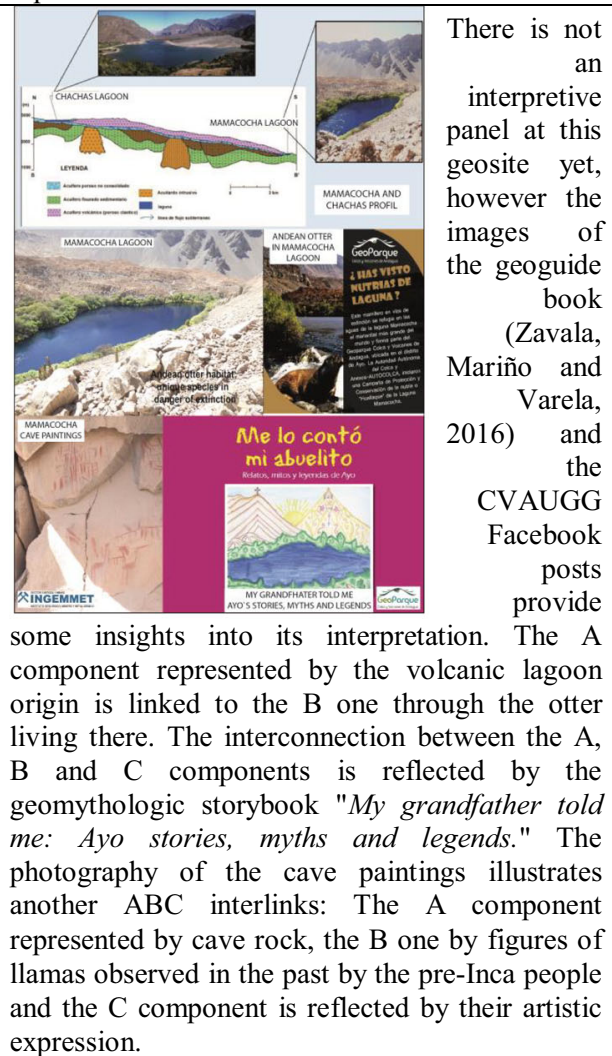 \\
\hline $\begin{array}{l}\text { Fossilized } \\
\text { remains of logs } \\
\text { Tururunca } \\
\text { Slopes of the } \\
\text { Tururunca hill } \\
(4,337 \text { masl), } \\
\text { west of the town } \\
\text { of Huambo, on } \\
\text { the left bank of } \\
\text { the Colca River. } \\
\text { It is accessed } \\
\text { from the } \\
\text { Huambo- } \\
\text { Pedregal } \\
\text { highway by a } \\
\text { paved trail. }\end{array}$ & $\begin{array}{l}\text { Fossilized log } \\
\text { fragments, } \\
\text { recrystallized in } \\
\text { sandstones of the } \\
\text { Hualhuani } \\
\text { Formation. } \\
\text { Paleontological } \\
\text { investigations have } \\
\text { revealed these fossils } \\
\text { as the first evidence } \\
\text { of paleoflora } \\
\text { (Metapodocarpoxylo } \\
\text { n) in the center-west } \\
\text { of the Gondwana of } \\
\text { the Jurassic } \\
\text { Cretaceous. } \\
\text { Similar log } \\
\text { fragments have been } \\
\text { found in the channel } \\
\text { of the Huambo } \\
\text { River. }\end{array}$ & $\begin{array}{l}\text { Surrounding slopes } \\
\text { in a northwesterly } \\
\text { direction with } \\
\text { abundant presence } \\
\text { of forests or } \\
\text { rodales of Puyas } \\
\text { de Raimondi } \\
\text { (Huankares), } \\
\text { queen of the } \\
\text { largest species of } \\
\text { bromeliad. } \\
\text { Its population } \\
\text { counts more than } \\
\text { 120 individuals (5 } \\
\text { individuals / ha). } \\
\text { Its landscape } \\
\text { condition } \\
\text { according to size is } \\
\text { classified } \\
\text { regular to low, } \\
\text { compared to others } \\
\text { in the Arequipa } \\
\text { region (Salazar and } \\
\text { Villasante 2012). }\end{array}$ & $\begin{array}{l}\text { The Tururunca hill is an } \\
\text { apacheta, a mountain } \\
\text { whose summit reaches } \\
4,669 \text { masl. It is part of } \\
\text { the watershed of the } \\
\text { Majes-Colca and } \\
\text { Quilca-Vitor basins. } \\
\text { One of the old footpaths, } \\
\text { before there was no road } \\
\text { that accessed the } \\
\text { Huambo municipality, is } \\
\text { the one that connects } \\
\text { Huambo with the Majes } \\
\text { Valley (Aplao) that } \\
\text { passes through the foot } \\
\text { of the Tururunca hill. }\end{array}$ & 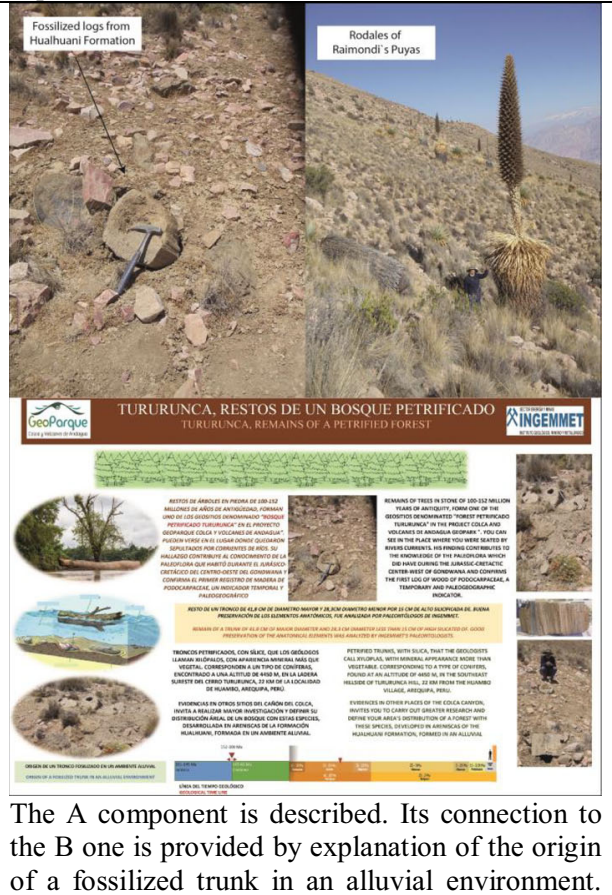 \\
\hline
\end{tabular}




\begin{tabular}{|c|c|c|c|c|}
\hline & & & & $\begin{array}{l}\text { The present-day unique vegetation and its } \\
\text { determination by the specific environment could } \\
\text { be mentioned. The same pays for the antient } \\
\text { human mobility through the foot of the Tururunca } \\
\text { hill. }\end{array}$ \\
\hline $\begin{array}{l}\text { Llunta Canyon } \\
\text { The Colca River } \\
\text { canyon sector. } \\
\text { In the vicinity of } \\
\text { the canyon, there } \\
\text { is an agricultural } \\
\text { landscape } \\
\text { developed by the } \\
\text { population of } \\
\text { Canocota } \\
\text { municipality. On } \\
\text { the slopes of the } \\
\text { canyon, } \\
\text { archaeological } \\
\text { remains are } \\
\text { visible. }\end{array}$ & $\begin{array}{l}\text { The canyon section } \\
\text { of the Colca River in } \\
\text { the Canocota sector } \\
\text { (Tuti), carved out on } \\
\text { fissure lava of the } \\
\text { Andagua volcanism. } \\
\text { The location of these } \\
\text { lavas in the valley } \\
\text { produced a closure } \\
\text { of the Colca River, } \\
\text { originating } \\
\text { paleolake, which } \\
\text { extends several } \\
\text { kilometers upstream. } \\
\text { This was broken } \\
\text { through later. There } \\
\text { is a viewpoint from } \\
\text { the Tuti-Chivay } \\
\text { highway; a recent } \\
\text { paved road leading } \\
\text { to Canocota accesses } \\
\text { the canyon. }\end{array}$ & $\begin{array}{l}\text { An iconic cultural } \\
\text { landscape created } \\
\text { by the agricultural } \\
\text { activity practiced } \\
\text { on lake deposits as } \\
\text { well as volcanic } \\
\text { soil on both banks } \\
\text { of the Colca River. } \\
\text { Terraces are } \\
\text { arranged on both } \\
\text { sides of the } \\
\text { canyon, with } \\
\text { greater extension } \\
\text { upstream at the } \\
\text { foot of the } \\
\text { Canocota } \\
\text { municipality. They } \\
\text { bring to the local } \\
\text { population the } \\
\text { typical local crops } \\
\text { consisting of the of } \\
\text { the basic grains } \\
\text { and potatoes. } \\
\text { Eventually, the } \\
\text { local residents use } \\
\text { to fish the trout in } \\
\text { the Colca River. }\end{array}$ & $\begin{array}{l}\text { The volcanic and river } \\
\text { landscape is combined } \\
\text { with archaeological rests } \\
\text { (circular storage } \\
\text { constructions called } \\
\text { colcas by the indigenous } \\
\text { Aymara) and pre- } \\
\text { Hispanic terraces } \\
\text { (andenes). } \\
\text { To appreciate them, it is } \\
\text { necessary to descend to } \\
\text { the Colca River. } \\
\text { On the left bank of the } \\
\text { river, there is a large } \\
\text { pre-Inca road that } \\
\text { connects Callalli, } \\
\text { Canocota and Chivay } \\
\text { communities. It is a } \\
\text { Collagua path on which } \\
\text { the trekking is carried } \\
\text { out. }\end{array}$ & $\begin{array}{l}\text { At this geosite, where the interpretive panel is } \\
\text { also still missing, the photos from the CVAUGG } \\
\text { Facebook shows the interpretation potential for } \\
\text { discovering of the ABC links (e.g. stone colcas } \\
\text { storing the local vegetable crops in the past). The } \\
\text { interpretation of andenes filled with the fertile soil } \\
\text { could reveal the ABC interlinks through the } \\
\text { paleolake's sediments and volcanic minerals. }\end{array}$ \\
\hline $\begin{array}{l}\text { Chachas lagoon } \\
\text { and countryside } \\
\text { Geoheritage } \\
\text { forms associated } \\
\text { with the } \\
\text { damming of the } \\
\text { Andagua River } \\
\text { due to the } \\
\text { emplacement of a } \\
\text { lava field in the } \\
\text { Pleistocene - } \\
\text { Holocene, at the } \\
\text { foot of the of } \\
\text { Chachas } \\
\text { community with } \\
\text { its pre-Hispanic } \\
\text { agricultural } \\
\text { terraces. }\end{array}$ & $\begin{array}{l}\text { Depression caused } \\
\text { by placement of } \\
\text { lavas of several } \\
\text { generations, to the } \\
\text { foot of the Chachas } \\
\text { village. It is fed by } \\
\text { the discharge of the } \\
\text { Andagua } r \text { River, } \\
\text { where a large } \\
\text { alluvial fan is } \\
\text { currently seen at its } \\
\text { mouth. } \\
\text { Approximately three } \\
\text { km downstream, the } \\
\text { drainage of the } \\
\text { lagoon is lost or } \\
\text { infiltrates below the } \\
\text { lava field. Terraced } \\
\text { slopes resth } \\
\text { platforms, built on } \\
\text { volcanic soil, occupy } \\
\text { a part of the } \\
\text { southwest flank of } \\
\text { the Puca Mauras } \\
\text { Chachas }\end{array}$ & $\begin{array}{l}\text { This eminently } \\
\text { agricultural district } \\
\text { excels in a } \\
\text { sophisticated use } \\
\text { of fertile volcanic } \\
\text { soils, which are } \\
\text { irrigated by gravity } \\
\text { and in a lower } \\
\text { percentage by rains } \\
\text { (dryland farming). } \\
\text { The main crops are } \\
\text { potato, wheat, corn } \\
\text { and beans. }\end{array}$ & $\begin{array}{l}\text { Chachas, titled as the } \\
\text { "Pearl of Castile } \\
\text { District" is a purely } \\
\text { agricultural and } \\
\text { livestock district. } \\
\text { There are two } \\
\text { communities located } \\
\text { near the lagoon: } \\
\text { Chachas and Nahuira. } \\
\text { The church of San Pedro } \\
\text { de Chachas, constructed } \\
\text { of the local volcanic } \\
\text { material, is one of the } \\
\text { oldest in the Castilla } \\
\text { province. It is estimated } \\
\text { that it was completed in } \\
\text { 1635, and it remains } \\
\text { very well preserved. } \\
\text { The Chachas lagoon, its } \\
\text { terraces and platforms as } \\
\text { well as its temple are } \\
\text { included in the shield of } \\
\text { arms of the Chachas } \\
\text { community, reflecting } \\
\text { thus its territorial }\end{array}$ & 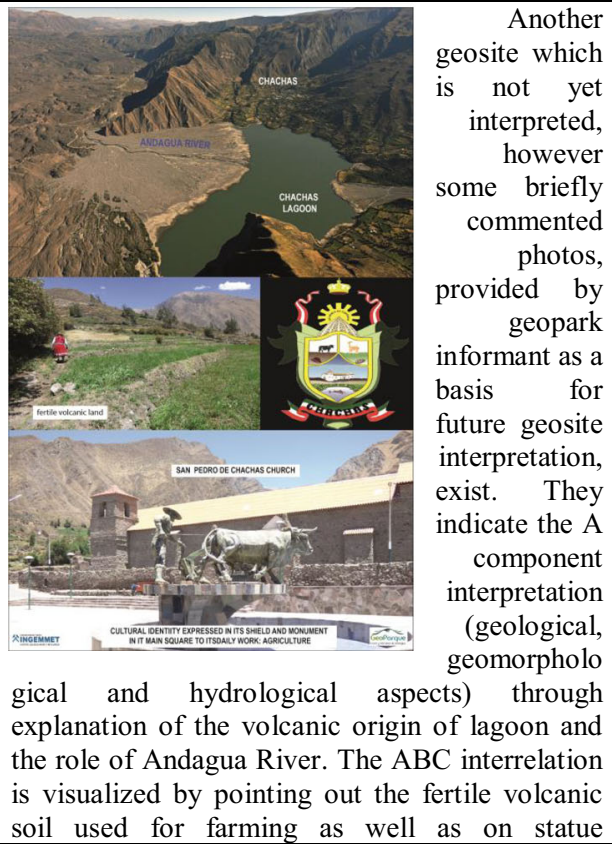 \\
\hline
\end{tabular}




\begin{tabular}{|c|c|c|c|c|}
\hline & $\begin{array}{l}\text { monogenetic cone } \\
\text { made up of lava. }\end{array}$ & & identity. & $\begin{array}{l}\text { expressing farming and the ancient church, both } \\
\text { built of the local volcanic stone. The same for the } \\
\text { shield of arms of the Chachas community which } \\
\text { integrates all the three Earth heritage components } \\
\text { (volcanic lagoon, cattle, camelids and terraces). }\end{array}$ \\
\hline $\begin{array}{l}\text { Colca Canyon } \\
\text { Tourist viewpoint } \\
\text { of the geopark, } \\
\text { where it is } \\
\text { possible to see } \\
\text { the greatest depth } \\
\text { of the Colca } \\
\text { Canyon and } \\
\text { observe the } \\
\text { iconic bird of its } \\
\text { territory: the } \\
\text { Andean condor. } \\
\text { The landscape } \\
\text { carved in the } \\
\text { walls of volcanic } \\
\text { origin, rugged } \\
\text { and deep. } \\
\text { Presence of the } \\
\text { local artisans } \\
\text { offering products } \\
\text { made from } \\
\text { alpaca wool and } \\
\text { some local food } \\
\text { products for daily } \\
\text { consumption. }\end{array}$ & $\begin{array}{l}100 \mathrm{~km} \text { long and } \\
\text { more than } 3,000 \\
\text { meters deep canyon } \\
\text { with pronounced } \\
\text { slopes in volcanic, } \\
\text { intrusive, } \\
\text { metamorphic and } \\
\text { sedimentary rocks. } \\
\text { Colluvial deposits, } \\
\text { flows of hanging } \\
\text { lavas and volcanic } \\
\text { plateaus, settled by } \\
\text { populations that } \\
\text { maintain their } \\
\text { ancestral traditions } \\
\text { and customs (mainly } \\
\text { connected to } \\
\text { agriculture). } \\
\text { It concentrates } \\
\text { geological aspects } \\
\text { that show volcano- } \\
\text { tectonic activity, hot } \\
\text { springs, waterfalls, } \\
\text { etc. and different } \\
\text { geological aspects of } \\
\text { the Precambrian- } \\
\text { Jurassic-Cretaceous- } \\
\text { Paleogene-Neogene. }\end{array}$ & $\begin{array}{l}\text { The Colca River } \\
\text { crosses the bottom } \\
\text { of the canyon } \\
\text { between } 2,950 \text { and } \\
1,150 \text { masl, } \\
\text { passing through } \\
\text { different ecological } \\
\text { levels; slopes with } \\
\text { farming terraces } \\
\text { using different } \\
\text { microclimates and } \\
\text { with rural } \\
\text { settlements on both } \\
\text { banks (Tapay, } \\
\text { Cabanaconde, } \\
\text { Conishua, Llanca, } \\
\text { Acopalca and } \\
\text { Choco). } \\
\text { The key viewpoint } \\
\text { called Mirador } \\
\text { Cruz del Cóndor, } \\
\text { an emblematic } \\
\text { Andean bird that is } \\
\text { perceived by } \\
\text { tourists as great } \\
\text { attraction for its } \\
\text { flight, and by } \\
\text { indigenous people } \\
\text { as a lord of the } \\
\text { canyon. }\end{array}$ & $\begin{array}{l}\text { Andeneria, system of } \\
\text { terraces used by farmers, } \\
\text { located on both sides of } \\
\text { the canyon, } \\
\text { constructions that come } \\
\text { from the Collaguas, } \\
\text { people of the pre-Inca } \\
\text { culture. } \\
\text { Manifestations of local } \\
\text { culture by the local and } \\
\text { indigenous people in } \\
\text { their traditional clothing, } \\
\text { practicing their customs } \\
\text { and rituals like El Pago } \\
\text { a la Tierra - payment to } \\
\text { the Mother Earth } \\
\text { (Pachamama) at } \\
\text { different times of the } \\
\text { year. } \\
\text { Pre-Hispanic } \\
\text { cobblestone roads, used } \\
\text { as trekking routes, } \\
\text { connected to hidden } \\
\text { villages. }\end{array}$ & $\begin{array}{l}\text { The A component (geological, geomorphological, } \\
\text { and hydrological) is interpreted in detail, however } \\
\text { too expertly. With an exception of two pictures of } \\
\text { the ancient fortress and path on columnar lavas, } \\
\text { the B and C components and their mutual } \\
\text { interrelation as well as their link to A component } \\
\text { are practically not reflected. E.g., the } \\
\text { determination of the iconic systems of agriculture } \\
\text { parcels (andenerias) by the specific geology, } \\
\text { geomorphology and hydrology, as well as } \\
\text { specifics of condor habitat should be mentioned. }\end{array}$ \\
\hline $\begin{array}{l}\text { Andagua } \\
\text { Volcanoes } \\
\text { Valley viewpoint } \\
\text { Natural } \\
\text { viewpoint in } \\
\text { Antaymarca, } \\
\text { which shows a } \\
\text { panoramic view } \\
\text { of the Andagua } \\
\text { Volcanoes } \\
\text { Valley. } \\
\text { combines It } \\
\text { geological } \\
\text { aspects of recent } \\
\text { emplacement of } \\
\text { lava in the valley } \\
\text { and pre-Hispanic } \\
\text { occupation in the } \\
\text { area, as well as } \\
\text { its current use of } \\
\text { fertile land and } \\
\text { natural products. }\end{array}$ & $\begin{array}{l}\text { Main sector of the } \\
\text { Andagua Volcanoes } \\
\text { Valley which } \\
\text { concentrates a } 360 \text { ० } \\
\text { view } 10 \text { of the } 24 \\
\text { existing } \\
\text { monogenetic cones. } \\
\text { Lava fields, where } \\
\text { municipalities such } \\
\text { as Andagua and } \\
\text { Soporo as well as an } \\
\text { agricultural } \\
\text { countryside are } \\
\text { located. At the foot } \\
\text { of the viewpoint, } \\
\text { there is a citadel } \\
\text { built of blocks of } \\
\text { basaltic andesites } \\
\text { from the Andagua } \\
\text { Volcanoes. It is a } \\
\text { landscape generated } \\
\text { by an Andean } \\
\text { volcanism during the } \\
\text { Pleistocene } \\
\text { Holocene. Slag }\end{array}$ & $\begin{array}{l}\text { The dominant } \\
\text { vegetation is } \\
\text { represented by } \\
\text { cacti species, one } \\
\text { of them with the } \\
\text { fruit called } \\
\text { sancayo (or sanky), } \\
\text { growing wild } \\
\text { there, thus being } \\
100 \% \text { ecological } \\
\text { (without any } \\
\text { agrochemicals or } \\
\text { pesticides). Its } \\
\text { consumption is like } \\
\text { any other fruit. } \\
\text { Currently, it is } \\
\text { used for its acid } \\
\text { flavor for } \\
\text { production of drink } \\
\text { known as the } \\
\text { sancayo sour } \\
\text { (mixed with pisco, } \\
\text { national drink) or } \\
\text { ice creams, among } \\
\text { others. Due to its }\end{array}$ & $\begin{array}{l}\text { At the foot of the } \\
\text { Antaymarca hill, there is } \\
\text { an outcrop of older } \\
\text { volcanic rocks in which } \\
\text { reddish slag fragments } \\
\text { stand out. Towards its } \\
\text { northeast side, there is a } \\
\text { pre-Inca construction, } \\
\text { entirely built of slaggy } \\
\text { and dark volcanic rock, } \\
\text { the Antaymarca Citadel. } \\
\text { The material used in } \\
\text { their enclosures or } \\
\text { dwellings, as well as in } \\
\text { funerary contexts, has } \\
\text { been elaborated of the } \\
\text { volcanic material ejected } \\
\text { from the monogenetic } \\
\text { cone called Ayapucara } \\
\text { or Canalla Mauras. Due } \\
\text { to their dark color, it is } \\
\text { not possible to recognize } \\
\text { these constructions from } \\
\text { a greater distance than } \\
100 \text { m. Walking on the }\end{array}$ & 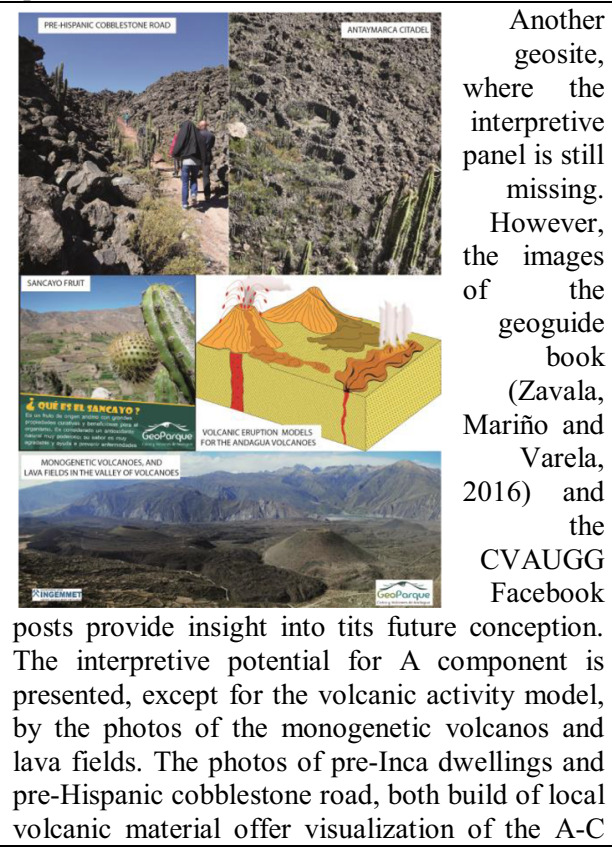 \\
\hline
\end{tabular}




\begin{tabular}{|c|c|c|c|c|}
\hline & $\begin{array}{l}\text { ones and lava flows } \\
\text { f various times can } \\
\text { e distinguished in } \\
\text { he ancient alluvial } \\
\text { alley. }\end{array}$ & $\begin{array}{l}\text { high content of } \\
\text { vitamin C and } \\
\text { potassium, it has } \\
\text { healing properties } \\
\text { (e.g. an antioxidant } \\
\text { effect). }\end{array}$ & $\begin{array}{l}\text { trails, the pottery } \\
\text { fragments from the place } \\
\text { can be observed. }\end{array}$ & $\begin{array}{l}\text { interlink. The simple interpretive text focusing on } \\
\text { the B component (cactus fruit sancayo and its } \\
\text { healing effects) exists. It should be enriched to } \\
\text { reflect ABC interlinks (specific soil } \\
\text { characteristics and the sancayo sour as a part of } \\
\text { local culture). }\end{array}$ \\
\hline $\begin{array}{l}\text { Colcas Shininea } \\
\text { Remains of } \\
\text { storage tanks, } \\
\text { called colcas, } \\
\text { located in the } \\
\text { canyon section of } \\
\text { the Colca River. }\end{array}$ & $\begin{array}{l}\text { The canyon section } \\
\text { of the Colca River in } \\
\text { the Yanque district, } \\
\text { made up of lake } \\
\text { deposits from the } \\
\text { Colca Formation } \\
\text { generated by a large } \\
\text { paleolake, caused by } \\
\text { a large volcanic } \\
\text { avalanche re that } \\
\text { dammed the Colca } \\
\text { River. The vertical } \\
\text { walls present } \\
\text { deformation } \\
\text { structures ("seismites } \\
\text { and slumps"), } \\
\text { frequently found in } \\
\text { somer sandstone } \\
\text { stratarar They } \\
\text { represent seismic } \\
\text { activity in the recent } \\
\text { geological past } \\
\text { associated with } \\
\text { neotectonics in the }\end{array}$ & $\begin{array}{l}\text { Suspension bridge } \\
\text { linking both banks } \\
\text { of the Colca used } \\
\text { by local people to } \\
\text { get to the grazing } \\
\text { areas with their } \\
\text { livestock (cattle } \\
\text { and camelids) and } \\
\text { to transport their } \\
\text { products. The } \\
\text { surrounding terrain } \\
\text { is used for farming. } \\
\text { On the Colca } \\
\text { paleolake deposits, } \\
\text { large platforms } \\
\text { were constructed to } \\
\text { stabilize slopes. A } \\
\text { few hundred } \\
\text { meters upstream, } \\
\text { "Colca of these } \\
\text { Amphitheater" or } \\
\text { andeneria, an } \\
\text { extraordinary } \\
\text { system of }\end{array}$ & $\begin{array}{l}\text { Pre-Inca stone buildings } \\
\text { of circular shapes, } \\
\text { colcas, dating back to } \\
800 \text { years ago. They } \\
\text { served as special } \\
\text { warehouses for the } \\
\text { conservation of seed } \\
\text { corn, quinoa and } \\
\text { potatoes. Its special and } \\
\text { whimsical location, on a } \\
\text { canned, refrigerated and } \\
\text { ventilated space. The } \\
\text { first Colca communities } \\
\text { (Collaguas) built large } \\
\text { warehouses to conserve } \\
\text { corn and meat charqui, } \\
\text { dried fruits, among other } \\
\text { products. The Colca } \\
\text { Valley and Colca } \\
\text { Canyon owe their name } \\
\text { to this ancient pantry of } \\
\text { this Andean region. }\end{array}$ & 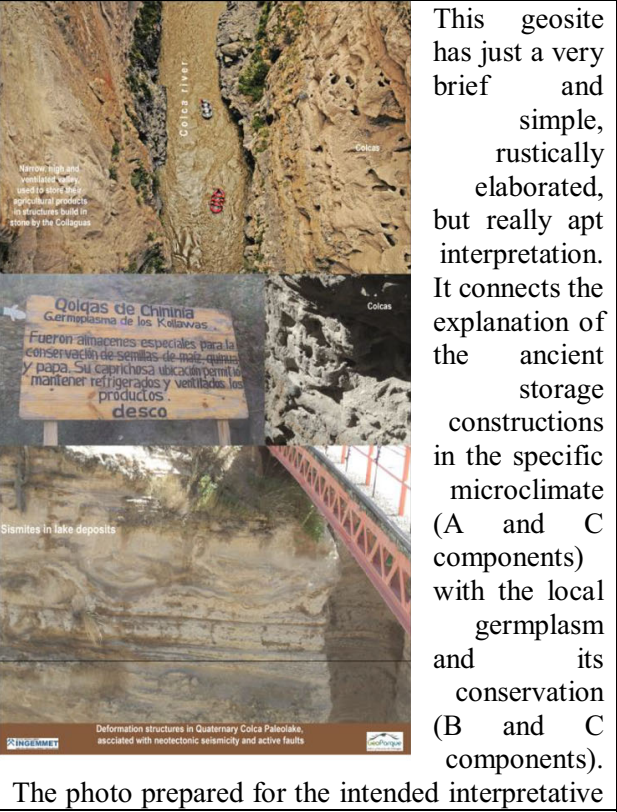 \\
\hline & $\begin{array}{l}\text { area. The greatest } \\
\text { thickness of this } \\
\text { paleolake } \\
\text { located in Yanque. }\end{array}$ & $\begin{array}{l}\text { pre-Hispanic } \\
\text { terraces, is located. }\end{array}$ & & $\begin{array}{l}\text { panel indicate this } \mathrm{ABC} \text { interlink as well, } \\
\text { stressing the cultural use of geomorphology of the } \\
\text { site. Another photo reflects local A component } \\
\text { (paleo-seismology and neotectonics). However, } \\
\text { the geological and geomorphological essence of } \\
\text { the site need to be interpreted, in connection to } \\
\text { colcas. }\end{array}$ \\
\hline $\begin{array}{l}\text { Small canyon } \\
\text { located south of } \\
\text { Orcopampa, } \\
\text { carved out on } \\
\text { folded and faulty } \\
\text { strata in Jurassic } \\
\text { sedimentary } \\
\text { rocks. A small } \\
\text { interior circuit } \\
\text { has been built, } \\
\text { where it is } \\
\text { possible to see an } \\
\text { ice waterfall, the } \\
\text { local flora } \\
\text { species a } \\
\text { waterfall. }\end{array}$ & $\begin{array}{l}\text { Hidden canyon, } \\
\text { south of Orcopampa } \\
(13.5 \mathrm{~km}) \text {, carved } \\
\text { out of Hualhuani } \\
\text { (Jurassic) quartz } \\
\text { sandstones. A small } \\
\text { waterfall and an } \\
\text { impressive seasonal } \\
\text { icefall (June-August) } \\
\text { can be observed } \\
\text { there. Large fallen } \\
\text { rock blocks, smooth } \\
\text { folding (anticline) on } \\
\text { the right side of the } \\
\text { valley and a normal } \\
\text { type geological fault } \\
\text { on the left side of the } \\
\text { valley are } \\
\text { remarkable. Clean } \\
\text { waters flow from the } \\
\text { Pacque gorge, from } \\
\text { the slopes of the } \\
\text { Chuañuma hill. The } \\
\text { local landscape is } \\
\text { result of the fluvial } \\
\text { and glacial erosion. }\end{array}$ & $\begin{array}{l}\text { The landscapes of } \\
\text { different } \\
\text { geological origin, } \\
\text { carved on } \\
\text { sandstones, are } \\
\text { complemented by } \\
\text { natural vegetation } \\
\text { and reduced } \\
\text { cultivation areas in } \\
\text { the valley. A } \\
\text { cobblestone circuit } \\
\text { trail shows the } \\
\text { flora of this place. }\end{array}$ & $\begin{array}{l}\text { From the main } \\
\text { viewpoint of this } \\
\text { canyon, it is possible to } \\
\text { observe the Challhua } \\
\text { Mauras volcano and the } \\
\text { snowy Coropuna, } \\
\text { venerated as Apu } \\
\text { (protective mountain } \\
\text { deities of the area). } \\
\text { Before entering this } \\
\text { geosite, it is possible to } \\
\text { see the ceramic work of } \\
\text { the local people called } \\
\text { tinajas; in evidently } \\
\text { offered in the direction } \\
\text { pointing to the snowy } \\
\text { Coropuna. }\end{array}$ & 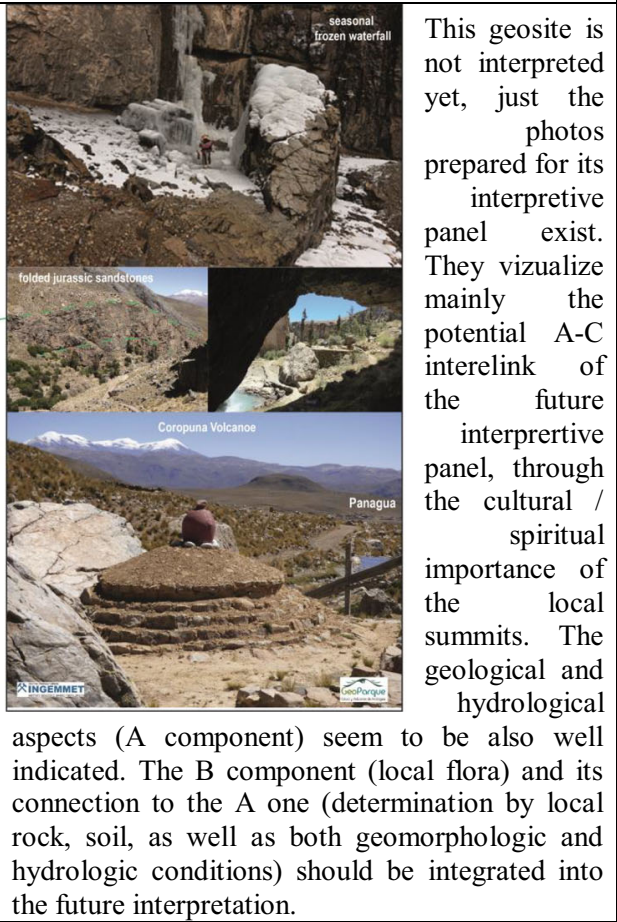 \\
\hline
\end{tabular}


Table 2 Analysis of the ABC concept application in the interpretation of the Muroto UNESCO Global Geopark

\begin{tabular}{|c|c|c|c|c|}
\hline \multirow{2}{*}{ Geosite } & \multicolumn{3}{|c|}{ ABC component of the geosite's Earth heritage } & \multirow{2}{*}{$\begin{array}{l}\text { Evaluation of the } \mathrm{ABC} \text { concept application in the geosite } \\
\text { interpretation }\end{array}$} \\
\hline & Abiotic (A) & Biotic (B) & Cultural (C) & \\
\hline $\begin{array}{l}\text { A small village, } \\
\text { called } \\
\text { Nakagawauchi, } \\
\text { located on a } \\
\text { fluvial terrace, } \\
\text { conserves local } \\
\text { tradition which } \\
\text { is very specific } \\
\text { compared with } \\
\text { life } \\
\text { communities in } \\
\text { the coastal area. } \\
\text { Hanegawa } \\
\text { River plays a } \\
\text { crucial role for } \\
\text { the } \\
\text { Nakagawauchi } \\
\text { community life } \\
\text { and } \\
\text { development. }\end{array}$ & $\begin{array}{l}\text { In } \\
\text { Nakagawauchi } \\
\text { village, } \\
\text { topography } \\
\text { formed by river } \\
\text { can be } \\
\text { observed; } \\
\text { fluvial terrace } \\
\text { which is a flat } \\
\text { land has the } \\
\text { village located } \\
\text { on it at an } \\
\text { elevation of ten } \\
\text { meters above } \\
\text { the river. Due to } \\
\text { its high altitude } \\
\text { from the river } \\
\text { surface, } \\
\text { village rarely } \\
\text { experiences } \\
\text { floods. } \\
\text { Therefore, } \\
\text { traditional } \\
\text { culture has been } \\
\text { conserved and } \\
\text { passed down for } \\
\text { many }\end{array}$ & $\begin{array}{l}\text { Hanegawa River } \\
\text { preserves high } \\
\text { water quality. } \\
\text { Since local } \\
\text { communities are } \\
\text { formed along the } \\
\text { river, locals have } \\
\text { spent their time by } \\
\text { the river, catching } \\
\text { river fish or } \\
\text { swimming in the } \\
\text { river. Local } \\
\text { elementary school } \\
\text { also did a water } \\
\text { quality survey } \\
\text { with local } \\
\text { residents; } \\
\text { evaluating its } \\
\text { quality based on } \\
\text { transparency and } \\
\text { species presence } \\
\text { in 2016 and 2017. }\end{array}$ & $\begin{array}{l}\text { Gicho Shrine is } \\
\text { located on this } \\
\text { fluvial terrace. In } \\
\text { the } 14^{\text {th }} \text { century a } \\
\text { samurai called } \\
\text { Gicho fled to this } \\
\text { area along with } \\
\text { his household, due } \\
\text { to trouble in his } \\
\text { political career. } \\
\text { This shrine hosts a } \\
\text { festival every } \\
\text { November in his } \\
\text { name. Locals } \\
\text { make } 263 \text { potato } \\
\text { cakes for the } 263 \\
\text { people who fled } \\
\text { with Gicho. } \\
\text { Nakagawauchi } \\
\text { also preserves a } \\
\text { traditional lion } \\
\text { dance performed } \\
\text { at Shinto festival, } \\
\text { praying for safety } \\
\text { of forestry work } \\
\text { and good harvest. }\end{array}$ & 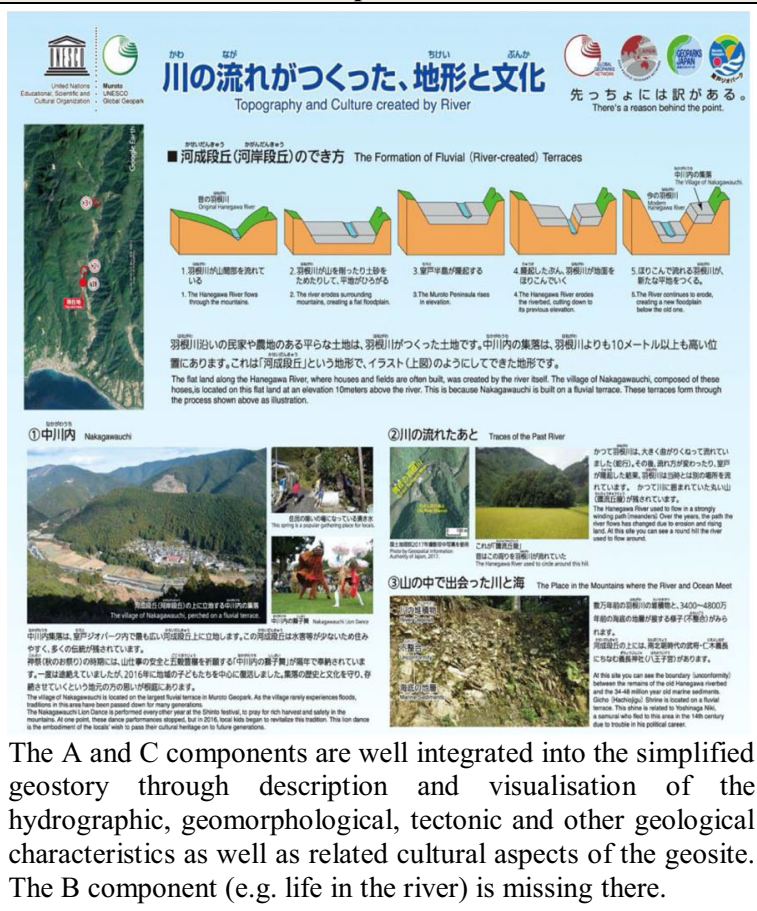 \\
\hline & generations. & & & \\
\hline $\begin{array}{l}\text { Nishiyama } \\
\text { plateau } \\
\text { It is area of } \\
\text { well-known } \\
\text { farm fields. } \\
\text { These flat lands } \\
\text { have been } \\
\text { cultivated by } \\
\text { villagers for } \\
\text { more than } 200 \\
\text { years. Local } \\
\text { community } \\
\text { continues in this } \\
\text { specific kind of } \\
\text { the agricultural } \\
\text { development. }\end{array}$ & $\begin{array}{l}\text { The step-like } \\
\text { shape of marine } \\
\text { terraces has } \\
\text { been formed by } \\
\text { the combination } \\
\text { of sea level } \\
\text { changes due to } \\
\text { climatic } \\
\text { variation and } \\
\text { coseismic } \\
\text { uplifts in the } \\
\text { western part of } \\
\text { Muroto. The flat } \\
\text { parts of the } \\
\text { terraces are } \\
\text { utilized for } \\
\text { farming, taking } \\
\text { advantage of the } \\
\text { favourable } \\
\text { terrain and rich } \\
\text { content of } \\
\text { minerals in the } \\
\text { soil. }\end{array}$ & $\begin{array}{l}\text { Many species of } \\
\text { fruit and } \\
\text { vegetables such as } \\
\text { sweet potatoes, } \\
\text { eggplants, various } \\
\text { types of the citrus } \\
\text { fruit or } \\
\text { watermelons are } \\
\text { grown on the } \\
\text { terraced fields } \\
\text { where they receive } \\
\text { abundant sunshine } \\
\text { and good drainage } \\
\text { (the land used to } \\
\text { be under the } \\
\text { ocean). Sea breeze } \\
\text { from the ocean } \\
\text { also gives a } \\
\text { beneficial stress } \\
\text { on crops which } \\
\text { makes them } \\
\text { specifically } \\
\text { delicious. }\end{array}$ & $\begin{array}{l}\text { Even after } \\
\text { cultivation of the } \\
\text { plateau by local } \\
\text { villagers, the } \\
\text { amount of water } \\
\text { for agriculture } \\
\text { was not sufficient } \\
\text { because of its } \\
\text { location. Local } \\
\text { inhabitants } \\
\text { therefore made } 23 \\
\text { reservoirs } \\
\text { various size in the } \\
\text { territory of the } \\
\text { community. } \\
\text { Thanks to these } \\
\text { reservoirs, } \\
\text { Nishiyama plateau } \\
\text { is well-known for } \\
\text { high-quality } \\
\text { agricultural crops. }\end{array}$ & 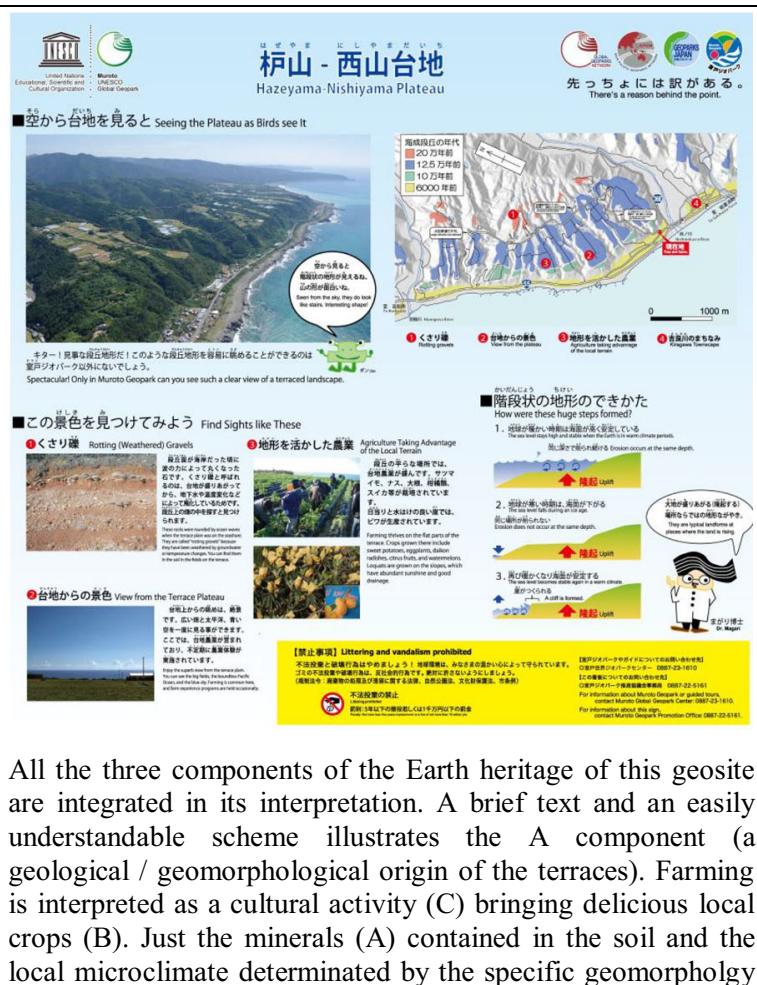 \\
\hline
\end{tabular}




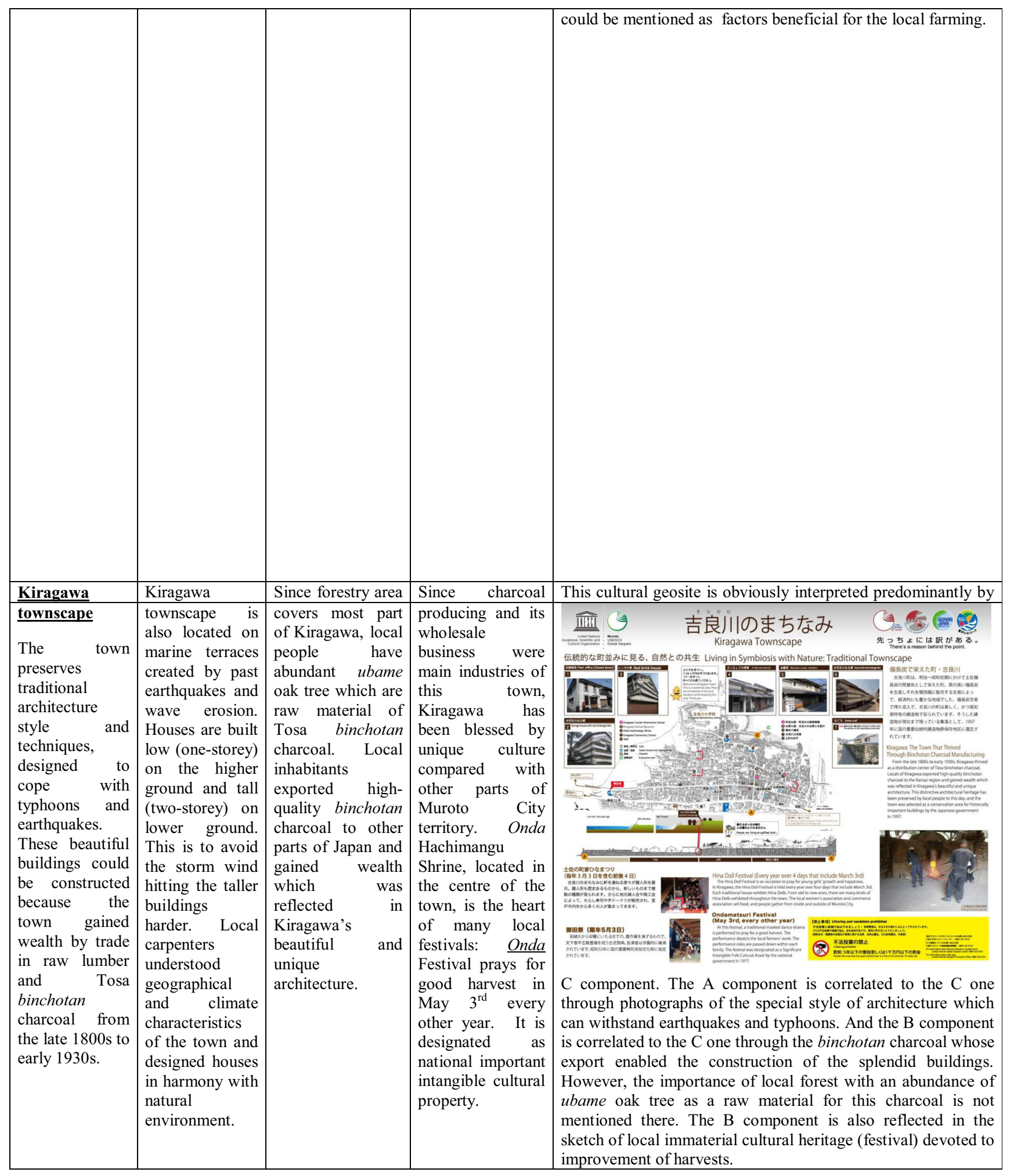




\begin{tabular}{|c|c|c|c|c|}
\hline $\begin{array}{l}\text { Murotsu Port } \\
\text { Murotsu Port }\end{array}$ & \begin{tabular}{lr}
\multicolumn{2}{l}{ Murotsu Port } \\
was built by \\
excavation
\end{tabular} & $\begin{array}{l}\text { The port is well } \\
\text { known landing } \\
\text { port for Kimme- }\end{array}$ & $\begin{array}{lr}\text { There are many } \\
\text { temples } \\
\text { shrines and }\end{array}$ & 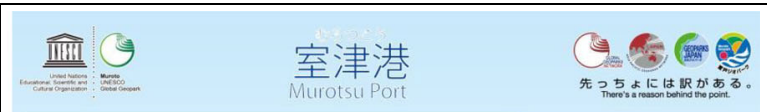 \\
\hline $\begin{array}{l}\text { area is the } \\
\text { biggest fishing } \\
\text { town in Muroto. } \\
\text { Many } \\
\text { restaurants and } \\
\text { local businesses } \\
\text { have started as } \\
\text { tuna-fishing } \\
\text { flourished from } \\
\text { the late } 1960 \mathrm{~s} \text {. }\end{array}$ & $\begin{array}{l}\text { bedrock. This } \\
\text { process had to } \\
\text { be repeated each } \\
\text { time an } \\
\text { earthquake } \\
\text { struck, uplifting } \\
\text { the land and } \\
\text { making the port } \\
\text { shallower. As } \\
\text { the land was } \\
\text { uplifted the port } \\
\text { was dug deeper, } \\
\text { creating the } \\
\text { difference in } \\
\text { height between } \\
\text { the sea level and } \\
\text { the buildings } \\
\text { that surround } \\
\text { the port. }\end{array}$ & $\begin{array}{l}\text { dai (alfonsina), } \\
\text { deep-sea fish. Off } \\
\text { shore of Muroto, } \\
\text { there are steep } \\
\text { cliffs and the } \\
\text { seabed suddenly } \\
\text { deepens near the } \\
\text { coast, which } \\
\text { provides deep-sea } \\
\text { fishing points } \\
\text { (400-700 m below } \\
\text { sea level) not far } \\
\text { from the port. } \\
\text { Kimme-dai is one } \\
\text { of the } \\
\text { representative } \\
\text { fishes of Muroto } \\
\text { Geopark. }\end{array}$ & 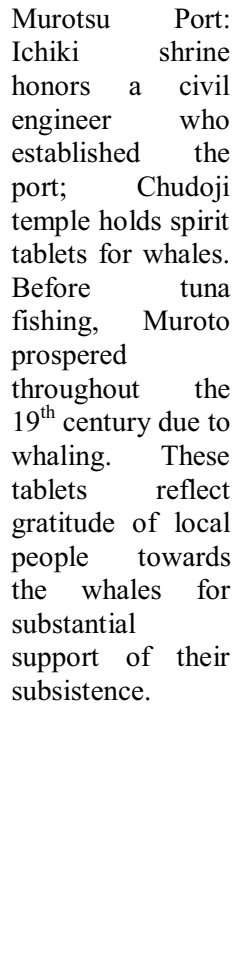 & $\begin{array}{l}\text { (2) } \\
\text { This is real example of the ABC concept application. All three } \\
\text { components are integrated in the text of the interpretive panel } \\
\text { as well as their mutual interlinks. The architecture and } \\
\text { urbanistic history reflect C component as a result of A } \mathrm{A} \text {. } \\
\text { component. The spiritual life reflected in the local temples (C) } \\
\text { is interconnected with life in the sea (B), because whaling } \\
\text { represented an important source of the local subsistence in the } \\
\text { past. The life in the deep see water is even connecting all the } \\
\text { three components: specific underwater geomorphology caused } \\
\text { by volcanic and tectonic activities in the past (A) enabling the } \\
\text { abundance of the Kimme-dai fish (B) which is the raw material } \\
\text { for the delicious dish as a part of the distinguished local cuisine } \\
\text { (C). }\end{array}$ \\
\hline $\begin{array}{l}\text { This geosite } \\
\text { shows that local } \\
\text { inhabitants } \\
\text { accept blessings } \\
\text { and struggles } \\
\text { brought to } \\
\text { Muroto by the } \\
\text { warm Kuroshio } \\
\text { current many } \\
\text { subtropical } \\
\text { flowers and } \\
\text { plants are } \\
\text { observed. On } \\
\text { the other hand, } \\
\text { this area had to } \\
\text { experience big } \\
\text { damage caused } \\
\text { by typhoons. }\end{array}$ & $\begin{array}{l}\text { Along the } \\
\text { Sakamoto } \\
\text { Coast, red rocks } \\
\text { with green and } \\
\text { white layers are } \\
\text { observed. It is } \\
\text { the result of } \\
\text { volcanic ash } \\
\text { that mixed with } \\
\text { mud on the sea } \\
\text { floor. Iron } \\
\text { within the } \\
\text { volcanic ash } \\
\text { oxidizes and } \\
\text { turns red. When } \\
\text { the amount of } \\
\text { iron is small, the } \\
\text { rock becomes } \\
\text { green or white. } \\
\text { These rocks } \\
\text { were used for } \\
\text { construction of } \\
\text { walls and as } \\
\text { garden stones. It } \\
\text { served also as } \\
\text { raw material for } \\
\text { production of } \\
\text { inkwells used in } \\
\text { calligraphy. }\end{array}$ & $\begin{array}{l}\text { Due to the warm } \\
\text { Kuroshio Current } \\
\text { off the coast of } \\
\text { Muroto, there is a } \\
\text { warm climate all } \\
\text { the year round. } \\
\text { Subtropical plants } \\
\text { are observed } \\
\text { throughout } \\
\text { Muroto. The } \\
\text { rapeseed blossoms } \\
\text { (na-no-hana in } \\
\text { Japanese) bloom } \\
\text { in this area first } \\
\text { within the City. } \\
\text { The name Nabae } \\
\text { comes from the } \\
\text { words na, } \\
\text { meaning rapeseed } \\
\text { blossom and bae } \\
\text { meaning to grow, } \\
\text { to live, or to } \\
\text { blossom. }\end{array}$ & 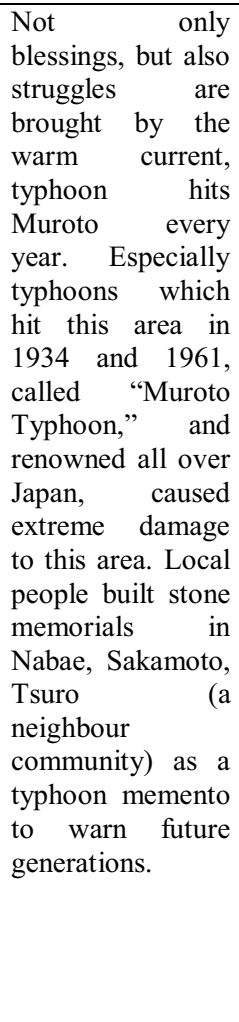 & 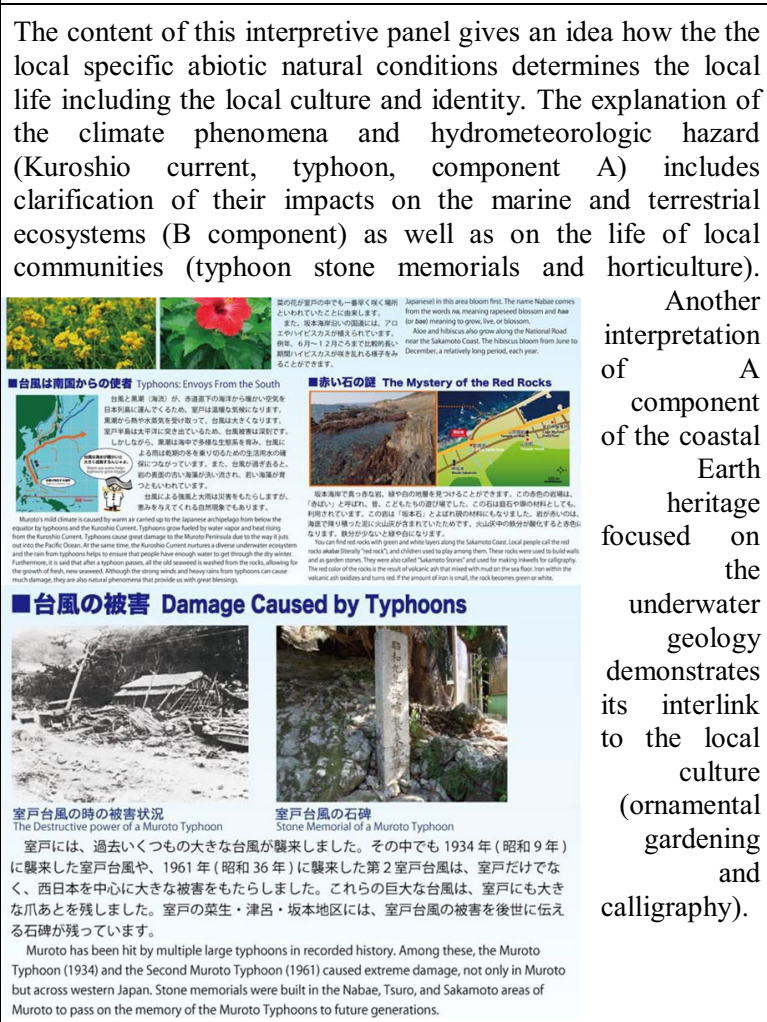 \\
\hline
\end{tabular}




\begin{tabular}{|c|c|c|c|c|}
\hline $\begin{array}{l}\text { Mitsu- } \\
\text { Maruyama } \\
\text { districts are } \\
\text { located in } \\
\text { eastern coast of } \\
\text { Muroto City, } \\
\text { where net- } \\
\text { fishing has been } \\
\text { traditionally } \\
\text { practised by } \\
\text { local } \\
\text { inhabitants. } \\
\text { Also, in this } \\
\text { area, deep sea } \\
\text { water industry } \\
\text { has flourished } \\
\text { since the 1990s. }\end{array}$ & $\begin{array}{l}\text { Maruyama coast } \\
\text { is extremely } \\
\text { flat, made up to } \\
15-28 \text { million } \\
\text { years old } \\
\text { mélange, } \\
\text { mostly } \\
\text { composed of } \\
\text { dark mudstone } \\
\text { surrounding } \\
\text { lighter chunks } \\
\text { of sandstone. } \\
\text { Beside the } \\
\text { mélange about } \\
\text { 14-million-year- } \\
\text { old igneous rock } \\
\text { (dolerite) is } \\
\text { observed. As } \\
\text { the harder } \\
\text { igneous rock is } \\
\text { more resistant to } \\
\text { erosion, it forms } \\
\text { a small } \\
\text { mountain, } \\
\text { sticking up near } \\
\text { the coast. } \\
\text { Kitano Shrine is } \\
\text { on the mountain } \\
\text { for fishery } \\
\text { prosperity. }\end{array}$ & $\begin{array}{l}\text { A large variety of } \\
\text { creatures live } \\
\text { along this shore } \\
\text { due to the } \\
\text { nutrient-rich deep } \\
\text { seawater disposed } \\
\text { of in the ocean by } \\
\text { a deep-sea water } \\
\text { laboratory. In } \\
\text { Mitsu Coast, } \\
\text { fossilized bivalve } \\
\text { group lived } \\
\text { (Akebiconcha } \\
\text { uchimuraensis) is } \\
\text { found. It lived } \\
\text { deep in the ocean } \\
\text { and survived using } \\
\text { methane and } \\
\text { sulphur that } \\
\text { bubbles up from } \\
\text { underwater vents. } \\
\text { It was designated } \\
\text { as a municipal } \\
\text { cultural property } \\
\text { in June 2019 by } \\
\text { local high school } \\
\text { students works. }\end{array}$ & $\begin{array}{l}\text { Muroto } \\
\text { Municipality is } \\
\text { blessed by under- } \\
\text { water topography } \\
\text { which nurtures } \\
\text { deep sea water. In } \\
\text { Muroto, deep sea } \\
\text { water research has } \\
\text { started in } 1989 \text { for } \\
\text { the first time in } \\
\text { Japan. Later, } \\
\text { private } \\
\text { companies, } \\
\text { handling deep sea } \\
\text { water, were } \\
\text { established along } \\
\text { the east coast of } \\
\text { Muroto. Deep sea } \\
\text { water industry } \\
\text { became a new } \\
\text { representative } \\
\text { industry } \\
\text { Muroto of which } \\
\text { creates employment } \\
\text { opportunities for } \\
\text { local people. }\end{array}$ & $\begin{array}{l}31 \text { tran } \\
1 \text { represented by both terrestrial } \\
\text { and geomorphologic phenome }\end{array}$ \\
\hline $\begin{array}{l}\text { Sakihama } \\
\text { prospered from } \\
\text { the late } 1800 \mathrm{~s} \text { to } \\
\text { the early } 1900 \mathrm{~s} \\
\text { by transporting } \\
\text { firewood and } \\
\text { binchotan } \\
\text { charcoal. The } \\
\text { mountainous } \\
\text { area } \\
\text { Sakihama in } \\
\text { formed a unique } \\
\text { culture, } \\
\text { different from } \\
\text { the coastal area. }\end{array}$ & $\begin{array}{l}\text { The Kanagi } \\
\text { area, located } \\
\text { upstream along } \\
\text { the } \\
\text { Sakihamagawa } \\
\text { River, has } \\
\text { suffered } \\
\text { repeatedly from } \\
\text { landslides } \\
\text { caused by } \\
\text { earthquakes and } \\
\text { heavy rains. } \\
\text { The landslides } \\
\text { buried } \\
\text { Sakihama port, } \\
\text { the communities } \\
\text { and farmlands } \\
\text { in the area. The } \\
\text { remains of the } \\
\text { restoration work } \\
\text { (1917 - 1964), } \\
\text { such as log } \\
\text { barriers and } \\
\text { stone dams, are } \\
\text { preserved and } \\
\text { they indicate } \\
\text { period's } \\
\text { construction } \\
\text { method. }\end{array}$ & $\begin{array}{l}\text { In the upstream } \\
\text { part of } \\
\text { Sakihamagawa } \\
\text { River (on the } \\
\text { slope at about } \\
675 \sim 900 \text { masl), } \\
\text { there are } 33 \text { large } \\
\text { wild cedar trees. } \\
\text { Some of them } \\
\text { have trunks } \\
\text { reaching up to } 13 \\
\text { meters in girth. } \\
\text { The inland area of } \\
\text { Muroto has many } \\
\text { steep slopes which } \\
\text { receive large } \\
\text { amount of rain, } \\
\text { making it a } \\
\text { favourable habitat } \\
\text { for cedar trees. } \\
\text { The cedar tree } \\
\text { community is } \\
\text { protected as a part } \\
\text { of national forest. } \\
\text { A local guide } \\
\text { association is } \\
\text { licenced to } \\
\text { conserve and offer } \\
\text { guided tour in the } \\
\text { area. }\end{array}$ & $\begin{array}{l}\text { At a lower altitude } \\
\text { from the wild } \\
\text { cedar tree } \\
\text { community, there } \\
\text { used to be a small } \\
\text { settlement called } \\
\text { "Dan". The local } \\
\text { people focused on } \\
\text { forestry until } \\
\text { around 1970s. The } \\
\text { number } \\
\text { foresters gradually } \\
\text { decreased, and the } \\
\text { remaining } \\
\text { families left the } \\
\text { mountain soon } \\
\text { after. In the } \\
\text { middle of tour to } \\
\text { wild cedar tree, an } \\
\text { elementary school } \\
\text { (closed in 1971), } \\
\text { can be observed. } \\
\text { The building still } \\
\text { remains rest of } \\
\text { period's local life } \\
\text { style. }\end{array}$ & 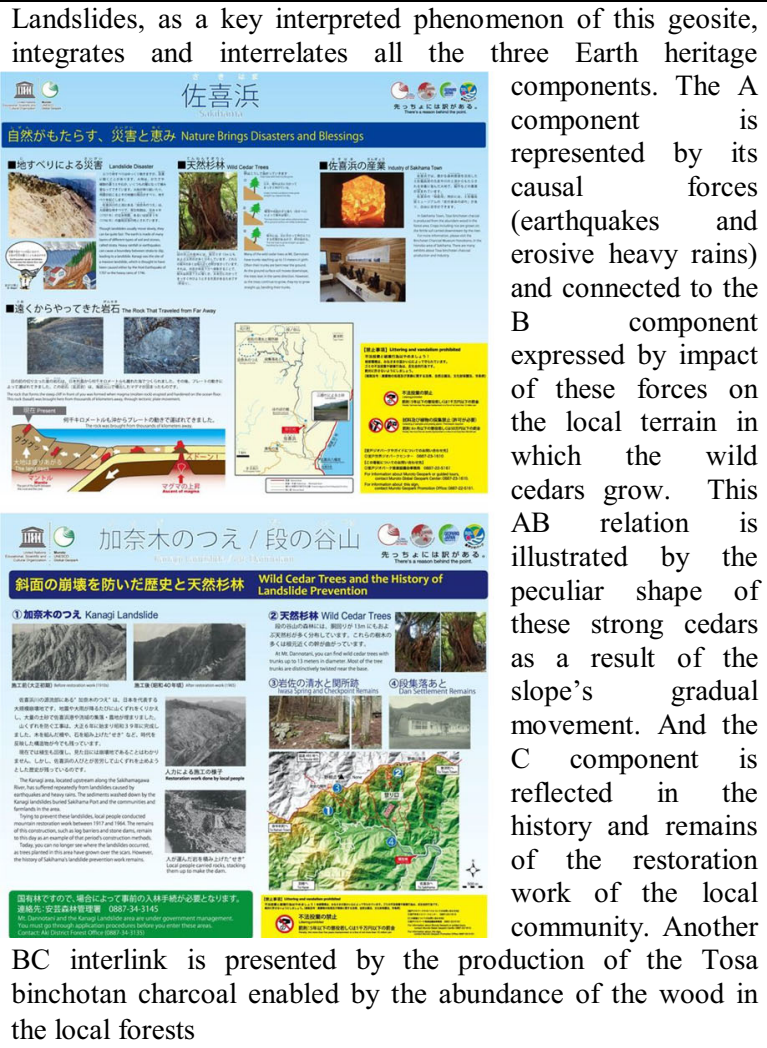 \\
\hline
\end{tabular}


the main geological features of the MUGG territory, has the biggest number of small panels. A small panel focuses on explaining specific rocks, geological phenomena, and ecosystems with easy words and graphics. Therefore, the small panel does not really tell visitors a holistic geostory which is a connection between nature and people's lives. A large panel, on the other hand, aims to show the connection and tells more comprehensive information of each geosites, more focusing on a contextual geostory. The large panel is easier to find compared with a small one, so visitors look first at the large one and then find small panels with more specific interpretations. The large panel has always on its left side the same interpretation giving through the brief text and simple graphics the key geostory of the geopark (Fig. 8). This brief text really reflects an $\mathrm{ABC}$ philosophy: "Where the Ocean and the Land Meet-The Forefront for the Birth of New Habitable Land. A Geopark is a park where you can feel the heartbeat of the Earth. Here you can experience first-hand the relationship between us and our planet Earth." This geostory always conveys to the visitor the notion of formation of the Muroto lands and integrates successfully the A, B, and C components of the MUGG Earth heritage. Through this system, the MUGG team is trying to explain geological phenomena in the context of the human and physical geography of the given geosite, e.g., a formation process of fluvial terrace with a simple illustration (see "Nakagawauchi Village on a Fluvial Terrace" in Table 2). It explains the process with words which conjured up illustration or photos when preventing the use of expert terms which are not important for understanding of the interpreted phenomena. The MUGG team also researched the cultural environment around the site, such as traditional festivals or local customs. Then the cultural and ecological information were put deliberately on a same interpretive panel with geological information. The fluvial terrace interpretive panel shows how local inhabitants have established their lifestyle on the terrace.

The interpretation method of Earth heritage has been changing day by day with local specialists who explain the situation and phenomena of their place by their own words. The MUGG geoscientists regularly work with a local guide association (Muroto City Tourist Guide Association) with the aim of improving the interpretive skills of local geological/ geographical phenomena. To develop a new geotrail, they investigate potential sites together and role-play for interpreting those sites. Throughout such interactions with local guides, the MUGG has improved its interpretive method of Earth heritage.

Moreover, the MUGG team has frequently interviewed senior locals to record cultural and historical events in the geopark territory. For example, they shared how the local traditional festivals have developed under the influences of local industries which are strongly connected to the local natural environment. There are legends or myths related to the local natural environment in the geopark territory which have been handed down from generation to generation. Such legendary stories are also important resources for the MUGG to know how Earth heritage in the region has been recognized and interpreted by locals. Local people are in the forefront to experience transformation of local natural environment. Their involvement, therefore, is crucial for initial Earth Science investigation and following Earth heritage interpretation in the MUGG territory.

\section{Discussion and Conclusion}

In the Colca and Volcanoes of Andagua UNESCO Global Geopark territory, there are many cultural sites which are interrelated with local geography and geology (ecological floors, stone use and other geological resources). However, mainly because of the recent designation of this area as a UNESCO global geopark and relatively difficult socioeconomic conditions, the $\mathrm{ABC}$ concept application is presently not sufficiently visible in the terrain interpretation. The terrain interpretation does not reflect the biotic and cultural components of the Earth heritage presented on the evaluated geosites in a sufficient way; the same applies to their explicit or implicit links to the abiotic components, to the concrete geological phenomena. It is obvious from the interpretive panels whose content is analyzed in Table 1. On the other hand, this interpretive approach was intuitively used in the process of geopark project promotion, e.g., during its presentation on the "Regional Workshop Geoparks in Latin America" (Zavala 2015).

According the CVAUGG team, the people involved in geopark work, actually absorbed the ABC concept as a "geopark philosophy." The CVAUGG team clearly perceives this concept as a way of integrating different aspects of Earth heritage by attracting professionals from different specialties to work together. According to the Andean worldview, transmitted by the local indigenous peoples from one generation to another, the cultural and natural aspects of Earth heritage cannot be mutually separated. The local and indigenous people highly appreciate the location of their communities, and they also express deep respect for what is provided by their environment, Mother Earth (Pachamama). It is a real strength of this geopark, the territorial identity and sustainability exhibited by intuitive perception of the value of the ecosystem services provided by the Mother Earth. The further reflection on the local community knowledge of Earth heritage in the geopark interpretation will help the CVAUGG team to develop genuine interpretative panels and geotrails, and mobilize local people as interlocutors.

Geological, geographical, or ecological study results (Earth science field in the broad sense) on the Muroto UNESCO Global Geopark area have been accumulated so far. Abiotic and biotic aspects out of $\mathrm{ABC}$ concept, therefore, have a firm 


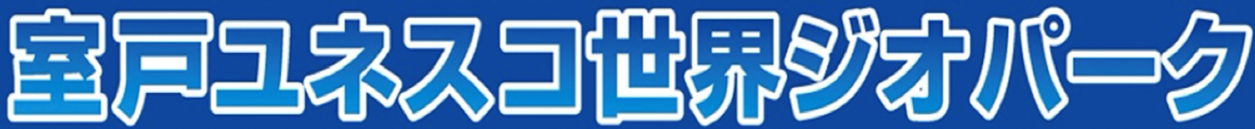 MUROTO UNESCO GLOBAL GEOPARK}
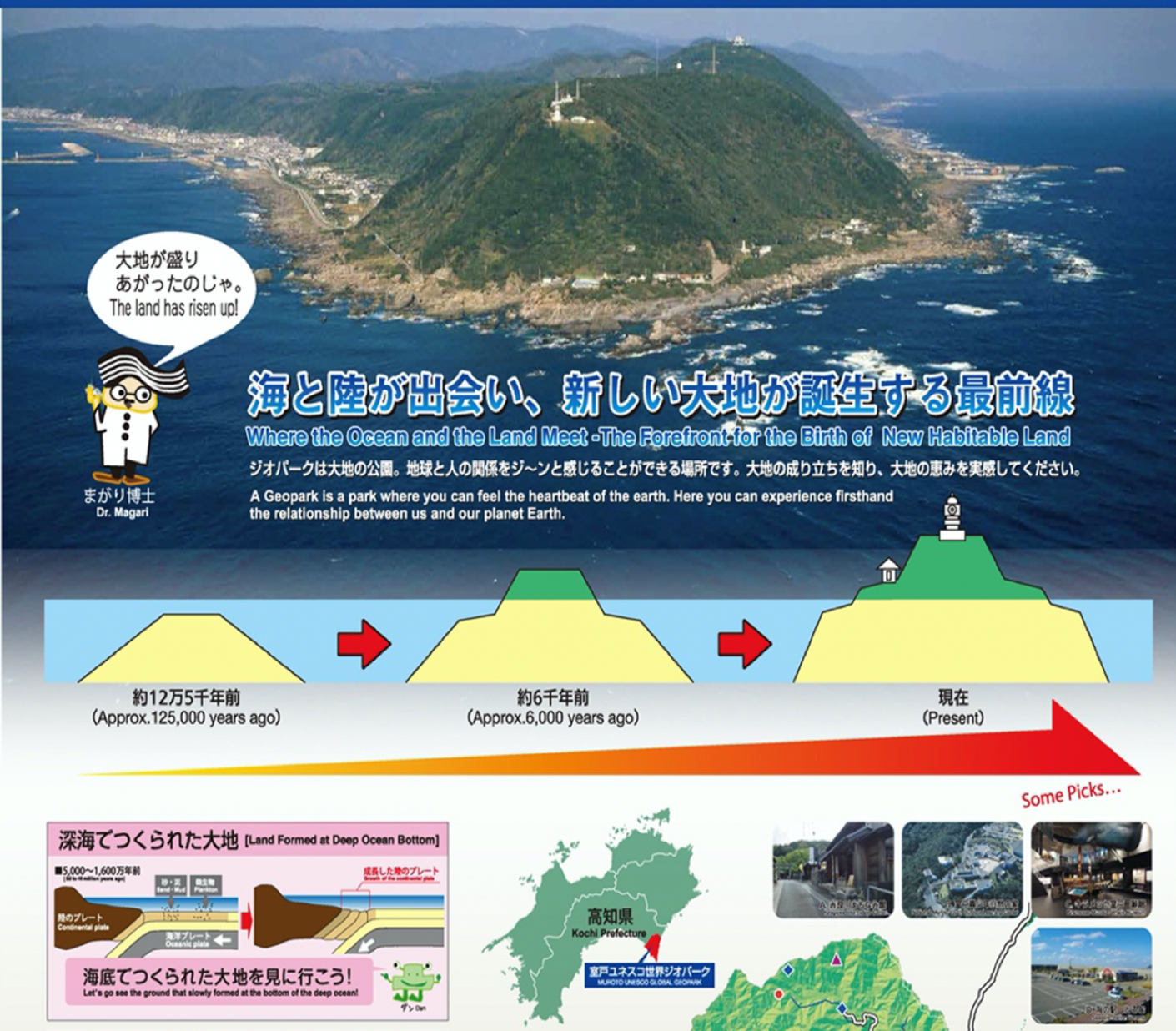

some Picks...
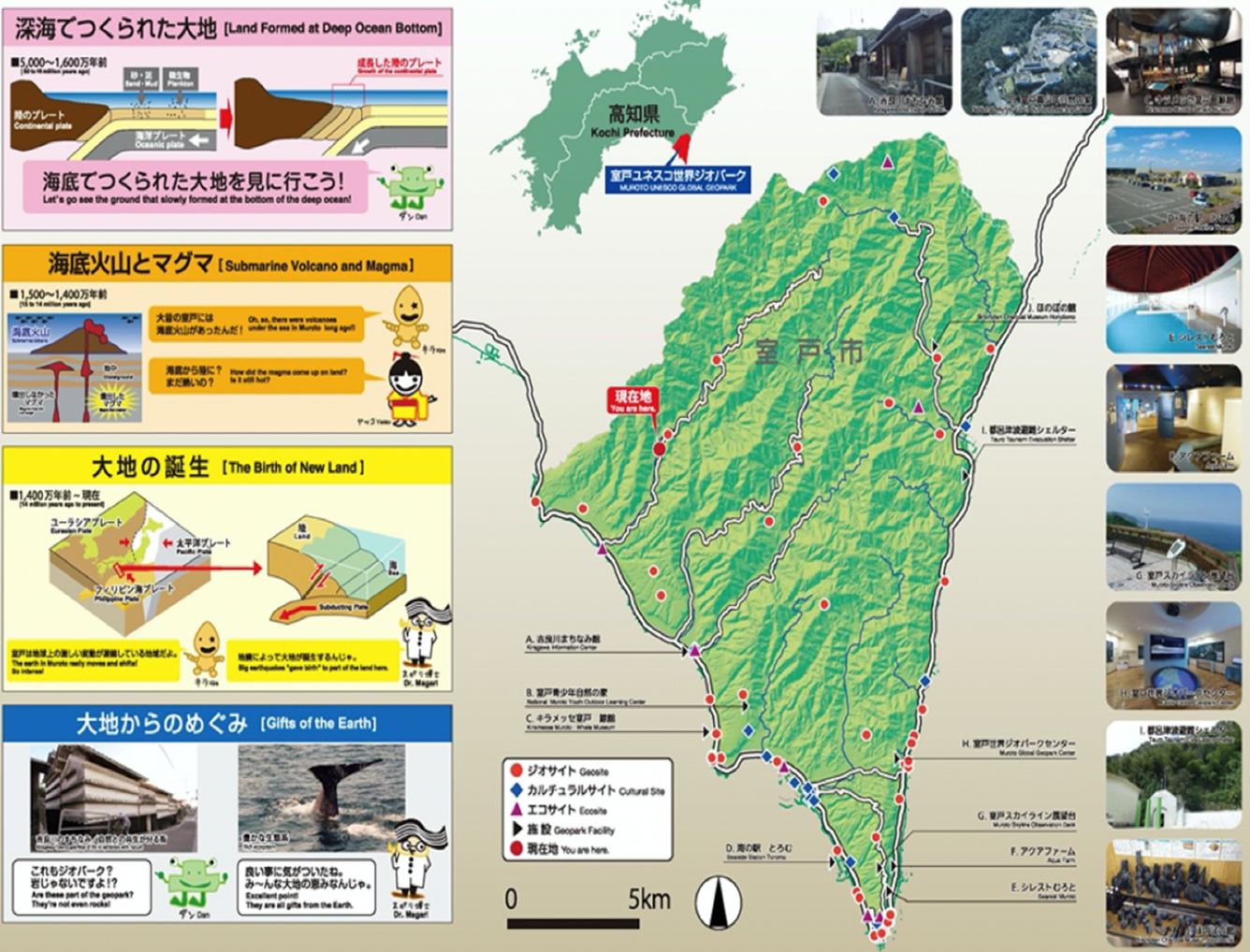

Fig. 8 The left side the of the large interpretive panel of the Muroto Geopark. Source: Muroto (2020) 
scientific background there. Cultural information, on the other hand, still needs to be considered and researched very carefully when shared on interpretive panels or communicated through guided tours. Scientific interpretation, such as land formation processes or fauna and flora related to the local climate environment, always becomes a foundation storyline of geostory which can be endorsed by the geopark Earth scientists. It tends to be believed that the cultural aspect is "added information" to the foundation storyline in the MUGG territory.

Moreover, when discussing "culture" as a term, there is a trend to base it on cultural information or events already summarized and written in a series of local history books edited and published by the Muroto Municipality, such as urban development, traditional industries, traditional festivals, or religious rituals. The MUGG had already a sort of "model" to show connections between culture (human lives) and Earth science. The content of the MUGG's interpretive panels, analyzed in Table 2, includes the local agriculture, fishery, or local festivals which are referred to show $\mathrm{ABC}$ connections in a whole geostory. Showing connections between human lives and Earth science is one of "models" because it is really easy to understand.

The MUGG should identify and protect its cultural "endemic phenomena," cultural specifics determined by the local specific climate and environment, found only in its territory, and performed just by the Muroto community. They need to be further transmitted and used in the Earth heritage interpretation, through application of the $\mathrm{ABC}$ concept. Due to the lack of anthropological research in the geopark area, some cultural information has not so far been documented. According to the MUGG team, it could be called as "local small narratives." For example, several Muroto communities have their unique cuisine or recipes which would reflect the community's characteristics nurtured by the local natural environment. The MUGG team conducts interview surveys to document and conserve such recipes and related immaterial heritage as a part of local knowledge on natural resources usage. That geocultural information can be shared at guided tours to show and explain the geopark Earth heritage comprehensively to its visitors. Although the MUGG exhibits high level of $\mathrm{ABC}$ concept application (and understandingly more mature interpretation in general than the recently designated CVAUGG), it needs to continue research and discussions dedicated to the cultural aspect to enrich further its geostories' development.

To sum up, the mutual $\mathrm{ABC}$ interconnections of the interpreted Earth heritage are well understood and perceived by both geopark teams. The MUGG team, after a process of development influenced by global geopark networking and knowledge sharing, applies the $\mathrm{ABC}$ concept in systematic and efficient way. In accordance with the left side of Fig. 2, the MUGG team has gradually developed its geoproducts in the specific environment determined and influenced by specific factors, and gradually learned to apply and enjoy the $\mathrm{ABC}$ concept. Nowadays, some of the interpretive panels located in this geopark can serve as a best practice example of application of this interpretive concept.

Regarding the CVAUGG case, it has to be considered that it is in the initial phase of its development. Without sufficient experience and knowledge transmission enabled by participation on networking, this geopark fails to apply the $\mathrm{ABC}$ concept at it touristically used geosites in all its breadth and depth. One important strength of the CVAUGG interpretation has been identified, which regards the local and indigenous people and geoguides, and other providers of tourism services. They are able to interrelate the local legends, myths, traditions, and cosmology, as well as both material and immaterial origin of cultural monuments with the geological and other natural heritage of their geopark. This ability is visible in the performance of local geoguides and some simple interpretive centers or booklets. The CVAUGG is evidently in a similar situation as was the MUGG in the past (left side of Fig. 2), consisting of the gradual learning by experience. Even though the local and indigenous people living in this geopark have the gift of an intuitive and naturally holistic perception of the Earth heritage, recognizing and interlinking all its three $(\mathrm{ABC})$ dimensions, the first generation of the CVAUGG interpretive panels do not significantly reflect this approach. The content of these panels is mainly focused on the geological components of the Earth heritage and frequently uses too many expert terms. On the other hand, there are also other, aforementioned interpretive materials and personal geoguiding in the CVAUGG, which manage to reflect the $\mathrm{ABC}$ concept.

The state of art of the ABC concept application in both geoparks is influenced mainly by the level of scientific knowledge and general education in the given geopark, as well as the level of knowledge management and length of networking with other UNESCO global geoparks. The ABC concept application can be considered as partially idiographic and partially nomothetic. There are some regular patterns that can be used in all the geoparks; however, their replicability is limited by the specific geographical settings, different stages of geopark product development, and different management approaches of the given territory. Among the key common patterns is the position of farming as an "interconnector" of the A, $\mathrm{B}$, and $\mathrm{C}$ components, including phenomena as local soil, climate, and gastronomy. The same applies to the position of immaterial cultural heritage, which reflects the geological/ geomorphological phenomena and processes, as well as the living nature determined by them in various religious, artistic, and other cultural expressions.

There is a high potential to apply the $\mathrm{ABC}$ concept in the frame of interpretation of rich Earth heritage of Colca and Volcanoes Andagua UNESCO Global Geopark and Muroto UNESCO Global Geopark, as well as of others geoparks. To 
further develop its application, interdisciplinary cooperation both in research and practice of each geopark is needed. Especially the transboundary disciplines like anthropogeography, ethnogeology, or the emerging special field called geomythology deserve attention of geoparks' practitioners and researchers in geoparks to empower their interpretation and to make their interpretive panels, guides, leaflets, and ICT-based means of interpretation more holistic and communicative.

Acknowledgements Project was funded by FIM UHK under the Specific Research Project "Information and knowledge management and cognitive science in tourism." The authors wish to express their thanks to Zuzana Kroulíková, a FIM UHK student, who assisted with the graphical elements of this study. They thank also to James Posso, for the photographs of geosites of the Colca Geopark and Andagua Volcanoes used in this article.

\section{Availability of Data and Material (Data transparency)} Code Availability Not applicable.

Author Contribution All authors have read and agreed to the published version of the manuscript. Conceptualization, M.P. and J.Z.; methodology, M.P.; validation, M.P.; formal analysis, M.P. and J.Z.; investigation, M.P., J.Z.; writing, M.P., J.Z., O.T, Z.B., and A.I.; supervision, M.P.; project administration, J.Z; funding acquisition, J.Z.

Funding This work was supported by FIM UHK.

\section{Declarations}

Conflict of Interest The authors declare no competing interests.

Open Access This article is licensed under a Creative Commons Attribution 4.0 International License, which permits use, sharing, adaptation, distribution and reproduction in any medium or format, as long as you give appropriate credit to the original author(s) and the source, provide a link to the Creative Commons licence, and indicate if changes were made. The images or other third party material in this article are included in the article's Creative Commons licence, unless indicated otherwise in a credit line to the material. If material is not included in the article's Creative Commons licence and your intended use is not permitted by statutory regulation or exceeds the permitted use, you will need to obtain permission directly from the copyright holder. To view a copy of this licence, visit http://creativecommons.org/licenses/by/4.0/.

\section{References}

Aranibar R, Ayerbe A (2015) Promotor forestal e innovaciones en las comunidades de Maca y Coporaque. Tesis para optar el grado académico de Licenciados en Antropología. Universidad Nacional San Agustín, Arequipa. Facultad de Ciencias histórico sociales, Escuela Profesional de Antropología, 130p

Azman N, Halim SA, Liu OP, Saidin S, Komoo I (2010) Public education in heritage conservation for geopark community. Procedia Soc Behav Sci 7:504-511. https://doi.org/10.1016/j.sbspro.2010.10.068

Benavente C, Delgado G, García B, Aguirre E, Audin L (2017) Neotectónica, evolución del relieve y peligro sísmico en la región
Arequipa. INGEMMET, Boletín, Serie C: Geodinámica e Ingeniería Geológica, 64, $370 \mathrm{p}$

Brilha J (2016) Inventory and quantitative assessment of geosites and geodiversity sites: a review. Geoheritage 8(2):119-134. https://doi. org/10.1007/s12371-014-0139-3

Brilha J, Gray M, Pereira DI, Pereira P (2018) Geodiversity: an integrative review as a contribution to the sustainable management of the whole of nature. Environ Sci Pol 86:19-28. https://doi.org/10.1016/ j.envsci.2018.05.001

Bruno DE, Crowley BE, Gutak JM, Moroni A, Nazarenko OV, Oheim KB, Ruban DA, Tiess G, Zorina SO (2014) Paleogeography as geological heritage: developing geosite classification. Earth Sci Rev 138:300-312. https://doi.org/10.1016/j.earscirev.2014.06.005

Caldas J (1993) Geología de los cuadrángulos de Huambo y Orcopampa. INGEMMET, Boletín, Serie A: Carta Geológica Nacional, 46, 62 p

Colca and Volcanoes Andagua (2020) Archive of the Colca and Volcanoes Andagua UNESCO Global Geopark

Committee MGP (2011) Progress report 2008-2011. Archive, Muroto Geopark

Committee MGP (2019) Progress report 2016-2019. Archive, Muroto Geopark

Crofts R (2019) Linking geoconservation with biodiversity conservation in protected areas. International Journal of Geoheritage and Parks 7(4):211-217. https://doi.org/10.1016/j.ijgeop.2019.12.002

de Carvalho CN (2014) Tourism in the Naturtejo Geopark, under the auspices of UNESCO, as sustainable alternative to the mining of uranium at Nisa (Portugal). Procedia Earth and Planetary Science 8:86-92. https://doi.org/10.1016/j.proeps.2014.05.018

Dowling RK (2013) Global geotourism - an emerging form of sustainable tourism. Czech Journal of Tourism 2(2):59-79

Du Y, Girault Y (2018) A genealogy of UNESCO global geopark: emergence and evolution. International Journal of Geoheritage and Parks, Darswin Publishing House 6(2):1-17

FACET (2018) Geotourism. A principal driver of Western Australia tourism. $15 \mathrm{p}$. , https://www.leisuresolutions.com.au/wp-content/ uploads/2015/02/Small-Geotourism-10-Point-Checklist1.pdf Accessed 26 January 2019

Farsani TN, Coelho C, Costa C (2009) Geotourism as an opportunity for local communities' participation in geoparks. Proceedings of 8th European Geoparks Conference, Idanha-a-Nova, Geopark Naturtejo, Portugal, p 89

Farsani TN, Coelho C, Costa C (2011) Geotourism and geoparks as novel strategies for socio-economic development in rural areas. Int J Tour Res 13(1):68-81. https://doi.org/10.1002/jtr.800

Farsani TN, Coelho C, Costa C (2013) Rural geotourism: a new tourism product. Acta Geoturistica 4(2):1-10

Farsani NZ, Mortazavi M, Bahrami A, Bizhaem FK (2017) Traditional crafts: a tool for geo-education in geotourism. Geoheritage 9(4):1-8. https://doi.org/10.1007/s12371-016-0211-2

Fassoulas CH, Mouriki D, Dimitriou-Nikolakis P, Iliopoulos G (2012) Quantitative assessment of geotopes as an effective tool for geoheritage management. Geoheritage 4(3):177-193. https://doi. org/10.1007/s12371-011-0046-9

Forte J, Brilha J, Pereira D, Nolasco M (2012) Quantitative evaluation of geodiversity: development of methodological procedures with application to territorial management. Geophys Res Abstr 14:8739

Fung CKW, Jim CY (2015) Unraveling Hong Kong Geopark experience with visitor-employed photography method. Appl Geogr 62:301313. https://doi.org/10.1016/j.apgeog.2015.05.014

Gentilini S (2016) GEOfood: local food for sustainable development. Geopark Global Geoparks Conference, English Riviera UNESCO Global, UK

Gordon JE (2018) Geoheritage, geotourism and the cultural landscape: enhancing the visitor experience and promoting geoconservation. Geosciences 8:136. https://doi.org/10.3390/geosciences 8040136 
Gray M (2008) Geodiversity: developing the paradigm. Proc Geol Assoc 119:287-298

Gray M (2011) Other nature: geodiversity and geosystem services. Environ Conserv 38(3):271-274. https://doi.org/10.1017/ S0376892911000117

Gray M (2020) Geodiversity, geoheritage and geoconservation for society. KeAi: International Journal of Geoheritage \& Parks. Available at SSRN: $10.2139 / \mathrm{ssrn} .3502050$, in print

Gray M, Gordon JE, Brown EJ (2013) Geodiversity and the ecosystem approach: the contribution of geoscience in delivering integrated environmental management. Proc Geol Assoc 124:659-673

Hilario, A. (2018). Comunicar Geología. Workshop for South and Latin America geopark projects. Flores, Uruguay - November 2018. (Presentation in Spanish).

Horner S, Swarbrooke J (2016) Leisure marketing. Routledge, London, UK

INAIGEM (2016) Glaciares en extinción. Diagnóstico de la situación actual en la Cordillera Chila. Informe Interno. Instituto Nacional de Investigación de glaciares y ecosistemas de Montaña, $\mathrm{p} 30$

Jaafar M, Shah A, Abdullah S, Marzuki A (2014) Geopark ecotourism product development: a study on tourist differences. Asian Soc Sci 10:42-55

Jaafar M, Shah A, Marzuki A, Abdullah S (2015) Development of ecotourism products in Kilim Geopark based on tourist perceptions. J Sustain Sci Manag 10:1-18. https://doi.org/10.5539/ass.v10n11p42

Kajima S, Tanaka Y, Uchiyama Y (2017) Japanese sake and tea as placebased products: a comparison of regional certifications of globally important agricultural heritage systems, geopark, biosphere reserves, and geographical indication at product level certification. Journal of Ethnic Foods 4(2):80-87. https://doi.org/10.1016/j.jef. 2017.05.006

Kirchner K, Kubalíková L (2015) Geomythology: a useful tool for geoconservation and geotourism purposes May 2015 Conference: public recreation and landscape protection - with man and hand in hand! In: Fialová J, Pernicová D Public recreation and landscape protection - with man and hand in hand! Conference proceeding, 3th-5th May 2015, Brno, 68-74. Mendel University in Brno

Kubalíková L (2013) Geomorphosite assessment for geotourism purposes. Czech Journal of Tourism 2(2):80-104. https://doi.org/10. 2478/cjot-2013-0005

Kubalíková L (2017) Mining landforms: an integrated approach for assessing the geotourism and geoeducational potential. Czech Journal of Tourism 6(2):131-154. https://doi.org/10.1515/cjot2017-0007

Kubalíková L (2020) Cultural ecosystem services of geodiversity: a case study from Stránská skála (Brno, Czech Republic). Land 9:105. https://doi.org/10.3390/land9040105

Málaga A (1986) Los andenes en la agricultura Collagua. In: De la Torre C, Burga M (eds) Andenes y camellones en el Perú andino: historia, presente y futuro. Lima, Consejo Nacional de Ciencia y Tecnología, pp 127-132

Martínez-Graña AM, Serrano L, González-Delgado JA, Dabrio CJ, Legoinha P (2017) Sustainable geotourism using digital technologies along a rural georoute in Monsagro (Salamanca, Spain). International Journal of Digital Earth 10(2):121-138. https://doi. org/10.1080/17538947.2016.1209582

Matsuki S, Sasao K (2015) Application of geostory as contents of tourism in the. Muroto geopark, geoparks and regional resources 1(1):19-25

Migoń P, Pijet-Migoń E (2016) Geoconservation and tourism at geothermal sites - lessons learnt from the Taupo Volcanic Zone, New Zealand. Proc Geol Assoc 127(3):413-421. https://doi.org/10. 1016/j.pgeola.2016.04.002

Migoń P, Pijet-Migoń E (2017) Viewpoint geosites - values, conservation and management issues. Proc Geol Assoc 128(4):511-522. https://doi.org/10.1016/j.pgeola.2017.05.007
Modrej D, Fajmut Štrucl S, Hartmann G (2018) Results of the geointerpretation research in the frame of the Danube GeoTour project. Geologija 61(1):101-110. https://doi.org/10.5474/geologija. 2018.007

Moroni A, Gnezdilova VV, Ruban DA (2015) Geological heritage in archaeological sites: case examples from Italy and Russia. Proc Geol Assoc 126(2):244-251. https://doi.org/10.1016/j.pgeola. 2015.01.005

Muroto (2020) Photo-archive of the Muroto UNESCO Global Geopark

Neches I-M (2016) Geodiversity beyond material evidence: a Geosite Type based interpretation of geological heritage. Proc Geol Assoc 127(1):78-89. https://doi.org/10.1016/j.pgeola.2015.12.009

Newsome D, Dowling R (2010) Setting an agenda for geotourism. In: Newsome D, Dowling R (eds) Geotourism: the tourism of geology and landscape. Goodfellow Publishers Limited, Oxford, pp 1-12

Newsome D, Dowling R, Leung Y-F (2012) The nature and management of geotourism: a case study of two established iconic geotourism destinations. Tour Manag Perspect 2-3:19-27. https://doi.org/10. 1016/j.tmp.2011.12.009

Pásková M (2018) Can indigenous knowledge contribute to the sustainability management of the aspiring Rio Coco Geopark, Nicaragua? Geosciences 8(8):277

Pásková M, Zelenka J (2018a) Sustainability management of UNESCO global geoparks. Sustainable Geoscience and Geotourism 2:44-64. https://doi.org/10.18052/www.scipress.com/SGG.2.44

Pásková M, Zelenka J (2018b) Společensky odpovědný cestovní ruch (Socially Responsible Tourism). IDEA Servis Prague

Paulo A, Gałaś A (2008) Polish research in Colca Canyon and Valley of Volcanoes/Polskie badania w Kanionie Colca i DolinieWulkanów. Kwartalnik AGH Geologia 34(2/1) (In Polish)

Ren F, Simonson L, Pan Z (2013) Interpretation of geoheritage for geotourism - a comparison of Chinese geoparks and national parks in the United States. Czech Journal of Tourism 2(2):105-125

Robles R (2008) Agricultura de riego y tradiciones en el valle del Colca. Revista de Antropología de la UNMSM, p:135-173

Rodrigues J, Carvalho CN (2009) Geoproducts in Geopark Naturtejo. In: Carvalho CN, Rodrigues J (eds.) Proceedings VIII European Geoparks Conference - new challenges with geotourism, Idanhaa-Nova, 14-16 September 2009 (Portugal), pp 82-86

Romero D, Ticona P (2003) Memoria descriptiva de la revisión y actualización del cuadrángulo de Huambo (32-r). Escala 1:50 0000. Informe INGEMMET, junio 2003. 29p, 4 mapas. Disponible en el Repositorio Institucional de INGEMMET, Lima, Perú. https://hdl.handle.net/20.500.12544/2056

Rutherford J, Newsome D, Kobryn H (2015) Interpretation as a vital ingredient of geotourism in coastal environments: the geology of sea level change, Rottnest Island, Western Australia. Tour Mar Environ 11(1):55-72. https://doi.org/10.3727/ $154427315 X 14398263718475$

Salazar J, Villasante F (2012) Distribución geográfica y situación actual de Puya raimondii Harms en la Región Arequipa, Perú. Octubre 2009-Marzo 2011. Quad Bot Amb APPL 23:31-39

Thomas MF (2016) New keywords in the geosciences - some conceptual and scientific issues. Revista do Instituto Geológico, São Paulo 37(1):1-12. https://doi.org/10.5935/0100-929X.20160001

Thouret JC, Wörner G, Gunnell Y, Singer BS, Zhang X, Souriot T (2007) Geochronologic and stratigraphic constraints on canyon incision and Miocene uplift of the Central Andes in Peru. Earth Planet Sci Lett 263(3-4):151-166. https://doi.org/10.1016/j.epsl.2007.07.023

Tomić N, Marković SB, Korać M, Mrđić N, Hose TA, Vasiljević DA, Jovičić M, Gavrilov MB (2015) Exposing mammoths: from loess research discovery to public palaeontological park. Quat Int 372: 142-150. https://doi.org/10.1016/j.quaint.2014.12.026

UNESCO (2015). Mentor report on Colca Canyon and Valley of Andahua Volcanos Geopark project, Perú. UNESCO internal material (not published), Paris 
UNESCO (2019). Revalidation mission report of the Muroto UNESCO Global Geopark. UNESCO internal material (not published), Paris

Vitaliano DB (2007) Geomythology: Geological origins of myths and legends. Geol Soc Lond, Spec Publ 273(1):1-7. https://doi.org/10. 1144/GSL.SP.2007.273.01.01

Yuhora K, Atsuko N, Hiroyuki K, Kuniyasuet M (2014) The role of geographical perspective in the development of geoparks. Ejournal GEO 9(1):13-25. https://doi.org/10.4157/ejgeo.9.13

Zavala B (2015) Propuestas de geoparques en Perú: El valle del Colca y valle de Volcanes de Andahua Geoparks and geoheritage; promoting geoheritage in Latin America. In: Regional Workshop Geoparks in Latin America, Institute of Geography, Mexico City, Mexico
Zavala B, Mariño J, Varela F (2016) Guía geoturística del valle de los volcanes de Andagua. INGEMMET, Boletín, Serie I: Patrimonio y Geoturismo 6:423 p

Zavala B, Churata D, Varela F (2019) Geodiversidad y patrimonio geológico en el valle del Colca (Geodiversity and Geological Heritage in Colca). INGEMMET, Boletín, Serie I: Patrimonio y Geoturismo 9:303 p

Zelenka J, Kacetl J (2013) Visitor management in protected areas. Czech Journal of Tourism 2(1):5-18. https://doi.org/10.2478/cjot-20130001

Zelenka J, Těšitel J, Pásková M, Kušová D (2013) Udržitelný cestovní ruch. Management cestovního ruchu v chráněných oblastech (Sustainable Tourism. Tourism Management in Protected Areas). Gaudeamus Hradec Králové 